\title{
Environmental impacts of producing bioethanol and biobased lactic acid from standalone and integrated biorefineries using a consequential and an attributional life cycle assessment approach
}

Parajuli, Ranjan ; Knudsen, Marie Trydeman; Birkved, Morten; Djomo, Sylvestre Njakou; Corona, Andrea; Dalgaard, Tommy

Published in:

Science of the Total Environment

Link to article, DOI:

10.1016/j.scitotenv.2017.04.087

Publication date:

2017

Document Version

Peer reviewed version

Link back to DTU Orbit

Citation (APA):

Parajuli, R., Knudsen, M. T., Birkved, M., Djomo, S. N., Corona, A., \& Dalgaard, T. (2017). Environmental impacts of producing bioethanol and biobased lactic acid from standalone and integrated biorefineries using a consequential and an attributional life cycle assessment approach. Science of the Total Environment, 598, 497512. https://doi.org/10.1016/j.scitotenv.2017.04.087

\section{General rights}

Copyright and moral rights for the publications made accessible in the public portal are retained by the authors and/or other copyright owners and it is a condition of accessing publications that users recognise and abide by the legal requirements associated with these rights.

- Users may download and print one copy of any publication from the public portal for the purpose of private study or research.

- You may not further distribute the material or use it for any profit-making activity or commercial gain

- You may freely distribute the URL identifying the publication in the public portal 
Environmental impacts of producing bioethanol and biobased lactic acid from standalone and integrated biorefineries using consequential and an attributional life cycle assessment approach

Ranjan Parajulia,*1, Marie Trydeman Knudsenª, Morten Birkvedb, Sylvestre Njakou Djomoa, Andrea Coronab, Tommy Dalgaarda

aDepartment of Agroecology, Aarhus University, Blichers Allé 20, DK-8830 Tjele, Denmark bDepartment of Management Engineering, Technical University of Denmark, Building 424, DK2800 Lyngby, Denmark ${ }^{*}$ Corresponding author, email: ranjan.parajuli@agro.au.dk, Phone: +4571606831

\section{Abstract:}

This study evaluates the environmental impacts of biorefinery products using consequential (CLCA) and attributional (ALCA) life cycle assessment (LCA) approaches. Within ALCA, economic allocation method was used to distributeimpacts among the main products and the coproducts, whereas within the CLCA system expansion was adopted to avoid allocation. The study seeks to answer the questions (i) what is the environmental impacts of process integration?, and (ii) do CLCA and ALCA lead to different conclusions when applied to biorefinery?. Three biorefinery systems were evaluated and compared: a standalone system producing bioethanol from winter wheat-straw (system A), a standalone system producing biobased lactic acid from alfalfa (system B), and an integrated biorefinery system (system C) combining the two standalone systems and producing both bioethanol and lactic acid. The synergy of the integration was the exchange of useful energy necessary for biomass processing in the two standalone systems. The systems were compared against a common reference flow: " $1 \mathrm{MJ} \mathrm{EtOH}+1 \mathrm{~kg}_{\mathrm{LA}}$ ", which was set on the basis of products delivered by the system C. Function of the reference flow was to provide service of both fuel (bioethanol) at 99.9\% concentration (ut. basis) and biochemical (biobased lactic acid) in food industries at 90\% purity; both products delivered at biorefinery gate. The environmental impacts of interest were global warming potential $\left(\mathrm{GWP}_{100}\right)$, eutrophication potential $(\mathrm{EP})$, non-renewable energy $(\mathrm{NRE})$ use and the agricultural land occupation (ALO). Regardless of the LCA approach adopted, system C performed better in all impact categories than both standalone systems. The process wise contribution to the obtained environmental impacts also showed similar impact pattern in both approaches. The study also highlighted that the recirculation of intermediate materials, e.g. $\mathrm{C}_{5}$ sugar to boost bioethanol yield and that the use of residual streams in the energy conversion were beneficial for optimizing the system performance.

Keywords: biobased products, attributional LCA, economic allocation, consequential LCA, biorefinery, indirect land use change, system expansion

\footnotetext{
${ }^{1}$ Alternative email address of the corresponding author: parajuliranjan@gmail.com
} 


\section{Introduction}

The increasing demand for biomass to biofuels has spurred the food vs fuels debates and has led to investigate the impacts of devoting croplands for biofuels production (Lange, 2007; Marris, 2006). Studies on $1^{\text {st }}$ generation biofuel production (based on food crops) have stressed on their poor environmental performance (Gressel, 2008; Mosier et al., 2005; Sims et al., 2010). Meanwhile, the environmental life cycle impacts of the $2^{\text {nd }}$ generation bioethanol production were also largely determined by the types of biomasses and the system boundaries considered for the assessment (Luo et al., 2010). Example, switchgrass, sugarcane and sugar beet showed varied environmental performance in the biofuel conversion pathway (Luo et al., 2010; Muñoz et al., 2013). Furthermore, direct and indirect land use change (d/iLUC) impacts, as expected to be induced during the production of biofuels and biobased products are also extensively debated (Khanna et al., 2011; Templer and van der Wielen, 2011). Moreover, biorefinery technologies are bringing new types of biobased products (Cherubini, 2010) on a comparable functional basis to fossil based products (Mickwitz et al., 2011) and also aimed at addressing such environmental consequences by producing both fuel and food/ feed commodities. Maximizing the values of biomass feedstocks by utilizing most of its components to produce both fuel and non-fuel products can be regarded as one of the sustainable solutions to manage the available biomasses to meet the future multi-fold demand of commodities (IEA, 2011; Parajuli et al., 2015).

Among the different biorefinery concepts, the green biorefinery (GBR) technology is seen as an alternative option for capitalizing the grassland biomass in Europe (Mandl, 2010; O'Keeffe et al., 2011). The GBR, until now, primarily aimed at producing protein in order to reduce the import dependency of livestocks feed (e.g. soy cake and soy meal) and also producing high value chemicals (e.g. lactic acid and lysine) (Kamm et al., 2009). Green protein is important in the livestock sector, whilst biobased lactic acid is important for the food, pharmaceuticals and chemical industries (Ghaffar et al., 2014; Kamm et al., 2009; Kim and Moon, 2001; O’Keeffe et al., 2011; Panesar et al., 2007; Thomsen, 2004; Wee et al., 2006). The global market production of biobased lactic acid in 2013 was 300-400 kilotons (ktons) (Harmsen et al., 2014). The production is expected to reach 800 ktons in 2020 (Dammer et al., 2013), driven by the demand of polylactic acid (Harmsen et al., 2014). In these contexts, biorefining of green biomasses is often seen as a sustainable path to deliver high value biobased products and also achieving many societal goals (IEA, 2011). Despite its technical viability are well described in many studies (Dale, 2003; Harmsen et al., 2014; Kamm et al., 2010; Kamm et al., 2009; O’Keeffe et al., 2011), environmental impacts of its products' value chains are limitedly studied (Parajuli et al., 2015).

Life cycle assessment (LCA) has been widely used as a tool for the assessment of environmental performance of different products and services (European Commission, 2015a). According to ISO (2006), the main phases of an LCA are (i) goal \&scope definition: where the product or service to be assessed is defined, a functional basis for comparison is chosen, (ii) inventory analysis: where the details on the data used for the assessment are discussed, (iii) impact assessment: where the effects 
of the resource use and the generated emissions are quantified into a limited number of impact categories, and (iv) interpretation of the results: where results are reported in the most informative way, along with the opportunities to reduce the impact of the product(s) or service(s). Furthermore, whenever, a product system involves multiple products, choices on the approach to handle the coproducts are unavoidably connected (Thomassen et al., 2008). With regard to the environmental evaluations of different biobased products, it is thus relevant to develop and apply standardized LCA methodologies that can cover the wide range of products delivered from a product system (European Commission, 2015b; ISO, 2006). This is generally carried out by using either; sub-dividing themultifunctional processes, system expansion and allocation (European Commission, 2010). In this context, attributional (ALCA) and consequential (CLCA) approaches were aimed to resolve the methodological debates over the allocation problems and also the choice of data (Thomassen et al., 2008). Within ALCA approach, allocation can be avoided by using system expansion to handle the co-products, but the co-product allocation is widely used (Thomassen et al., 2008). In general, if avoiding allocation is not possible, the ISO series (ISO, 2006) recommends using methods that reflects the physical relationship, such as mass and energy content or using other relevant variables to allocate, such as economic value of the products (Guinée et al., 2004). In the current study, economic allocation method was used, as is most frequently used (Crown and Carbon Trust, 2008). Within CLCA approach, avoiding allocation by system expansion is the only acknowledged way to deal with the co-products (Weidema, 2003). Moreover, it is also relevant to examine, whether the choice of any of the methods would end-up with different conclusions on the environmental ranking of any product system. Within such scope, comparative assessments usingALCA and CLCA approach were also practiced in various studies, e.g. as reported in Thomassen et al. (2008) and Sanchez et al. (2012).

This study aims at evaluating the environmental impacts of biorefinery products using a LCA method. Evaluations were made for two standalone biorefinery plants, separately producing bioethanol (system A) and biobased lactic acid (system B), and was compared with an integrated system (system C) producing the both stated products. The integrated system was termed in accordance to the definitions for "process integration" and "feedstock and product integration" (Stuart and El-Halwagi, 2012). The integration aimed to assess possible synergies between two different plants, so that they can be constructed at the same place to optimally utilize the resources and minimize the related burdens of logistics. Evaluation was carried out by using both ALCA and CLCA approach.

\section{Materials and methods}

\subsection{Goal and scope}

The goal of the current study is to evaluate and compare two standalone biorefinery systems with an integrated biorefinery plant, which combine the two standalone systems on the basis of the possible synergy between them. The study also examined whether CLCA and ALCA approach considered for the environmental evaluation of biorefinery systems would arrive with same conclusions. 


\subsection{System boundaries, functional units and environmental impact categories}

The evaluation covered the production and conversion of two different biomasses to produce two biobased products in an integrated biorefinery system (system C). The assumed geographical boundary was Denmark. A comparative assessment was made between system $\mathrm{C}$ and the two standalone systems, and the evaluation is categorized into three scenarios. In the first scenario, wheat straw is converted to bioethanol in a standalone plant (system A), while in the second scenario alfalfa is converted to biobased lactic acid in another standalone biorefinery (system B). In the third scenario, both bioethanol and biobased lactic acid are produced from wheat straw and alfalfa, respectively, through the development of an integrated biorefinery plant (system $\mathrm{C}$ ). In the comparative assessment, such as the case discussed in this study, it is important to use the same system boundaries and the same functional unit (FU) (EC, 2010). The system boundaries of the evaluated systems are shown in Figs. 1-3. Combination of output products was one of the suggested approaches to define FU in LCA studies related to biorefinery (Ahlgren et al., 2015). Hence, to compare system $\mathrm{C}$ with system $\mathrm{A}$ or system $\mathrm{B}$, both products (bioethanol and biobased lactic acid) produced from system $\mathrm{C}$ was considered as the main products. In this study, the FU was defined as the production of a certain amount of bioethanol (@ 99.5\% concentration) and biobased lactic acid (with $90 \%$ purity) for use in transport and food industries, respectively. The reference flow was thus a basket of ( $\left.1 \mathrm{MJ}_{\mathrm{EtoH}}+1 \mathrm{~kg}_{\mathrm{LA}}\right)$, and the products delivered at the biorefinery gate. For a system that generates only bioethanol or only biobased lactic acid, a 'conventional' standalone ethanol plant or lactic acid plant is assumed to cover the ethanol or lactic acid deficit, respectively. In order words, if the standalone systems are to be developed then the deficit products have to be supplied externally, as shown in Figs 1-2. A similar approach was used to define FU, and was considered to compare different agriculture systems (Marton et al., 2016), bioenergy system (Djomo et al., 2015) and for evaluating biorefinery systems (J ungmeier et al., 2013).

Fig. 1. Resource flow and system boundary of system A. Electricity produced represents net values of the system (i.e., plant's own consumptions are subtracted). The dotted lines indicate the avoided products considered in the CLCA approach.

Fig. 2. Resource flow and system boundary of system B. Electricity produced represents net values of the system (i.e., plant's own consumptions are subtracted). The dotted lines indicate the avoided products considered in the CLCA approach.

Fig. 3. Resource flow and system boundary of system C. Electricity produced represents net values of the system (i.e., plants' own consumptions are subtracted). The dotted lines indicate the avoided products considered in the CLCA approach.

The selected environmental impact categories were: Global Warming Potential (GWP(100), Eutrophication Potential (EP), Non-Renewable Energy (NRE) use and Agricultural Land Occupation (ALO). The first three impact categories were assessed using the "EPD” method (Environdec, 2013), while the ALO was evaluated using the ReCiPe method (Goedkoop et al., 2009). The selected 
environmental impact categories were among the ISO preliminary list (ISO, 2006) and are relevant whenever a production system and process are to be evaluated for minimizing agroecological problems, such as induced due to GHG emissions, nutrient enrichments and resource use (fossil fuel and land use). The selected environmental impact categories has also intended to consider both local and global effects, in order to avoid the situation "the unintended increase of global impact is avoided while trying to reduce local impact, or vice-versa" (van der Werf and Petit, 2002). Mitigation opportunities to reduce GHG emissions implemented in one geographical setting can be regarded useful to address the global climate change issues. Likewise, assessing eutrophication potential, a regional or local effect (Smith et al., 1999) helps to examine means of reducing nutrients losses and emissions by management of resources, e.g. utilizing residual waste of biorefineries as fertilizer. Likewise, impacts of fossil fuel depletion and occupation of agricultural land are relevant in the current issues of resource use (Parajuli, 2016; Parajuli et al., 2015). The modelling for impact assessment was facilitated by the use of the LCA software "SimaPRO 8.0.4" (PRé Consultants, 2015), which incorporates the stated assessment methods.

\subsection{Assessment approach}

In the current study, after the basket of main products was defined for FU, other co-products were handled by using both system expansion and allocation methods. Within system expansion, an approach of CLCA was used to substitute the remaining co-products, as they have market values (Table 2). Within ALCA, economic allocation method was used. Results obtained within CLCA and ALCA approach for the identified biobased products were also compared under two criteria: first, to determine if they consistently show similar impact pattern, e.g. on the environmental savings compared to the conventional counterparts, differences on the net environmental impacts obtained for the standalone systems and integrated system. The next criterion was the hotspot identification.

\subsubsection{CLCA approach}

In CLCA approach, whenever straw was involved as principal raw material to biorefinery, the assessment included consequences of removing straw. Consequences were assessed relative to a situation where straw is ploughed back to soil (Petersen and Knudsen, 2010). The consequences were, in terms of: (i) emissions due to soil organic carbon (SOC) change (ii) compensation of displaced nutrients by synthetic fertilizer and (iii) related $\mathrm{N}$ emissions avoided due to the straw removal process. With regard to alfalfa, its environmental impacts were calculated based on the input-output data, representative to the production from Danish arable land (NaturErhvervstyrelsen, 2015; SEGES, 2010; SEGES, 2015). Data inputs for the biomasses production are detailed in section 2.5 .

Within CLCA approach, the identification of the main products (bioethanol and biobased lactic acid) was based on the potential revenue generated from the products, calculated from the market price and the produced mass of the selected biobased products (Figs. 1-3 and Table 2). The co-products 
were assumed to partially substitute the corresponding marginal products (Figs.1-3). Marginal products were assumed undergoing substitutions by the corresponding biobased products (Table 1).

\subsubsection{ALCA approach}

Within ALCA approach, the total environmental impacts of each biorefinery system were partially allocated between its products and co-products using the method of economic allocation. Allocation factors were calculated considering the market price of each product (Table 2) and the quantity of products generated by each biorefinery systems (Figs. 1-3). A basket of two products (bioethanol and biobased lactic acids) was again considered as the main products, and thus allocation factors were estimated, which were based on the prices of each product. The calculated factors were: biobased lactic acid plus bioethanol (70\%) in system C; system A had 83\% and system B (82\%). Within ALCA approach, the environmental impacts of the straw production was based on the study reported by Parajuli et al. (2016).

Table 1. Biobased products and assumed substitutable products in the conventional market.

\subsection{Basic assumptions and data sources}

The basic assumptions related to this study are summarized in Table 2, unless otherwise are stated in the text below. Life Cycle Inventory (LCI) of the product systems covered both; the background and foreground processes (Figs. 1-3). The background process covered the environmental impacts of producing materials and energy entering to the foreground level. Emission factors for the production of assumed material inputs were based on Ecoinvent v3 (Weidema et al., 2013). The foreground process is the biorefinery system, covering the production and supply of the selected biomasses and their conversion into the selected biobased products.

The materials and energy input entering to system A were: straw (( 1 t, 85\% dry matter (DM)), enzyme, chemicals, water, heat and energy. The carbohydrate content of straw (system A) was assumed as 76\% (Møller et al., 2005). Materials entering to biorefinery were calculated from the studies reported by Bentsen et al. (2006), Kaparaju et al. (2009) and Wang et al. (2013). The mass flow during the straw conversion to bioethanol is shown in the Supporting information/ data (SI)-5 (Fig. S-5.1). Data on the potential environmental impacts (particularly, GHG emissions, EP and NRE use) related to the production of enzyme (Cellic CTec3) was obtained from Novozymes (Kløverpris, J.H, 2016, pers. comm.).

With regard to system B, the carbohydrate content of alfalfa was set to 56\% (Møller et al., 2005). Crude protein (CP) and lactic acid content in the ensiled alfalfa were assumed as $15 \%$ and $6 \%$ of the total DM biomass respectively (Møller et al., 2005; O’Keeffe et al., 2011) (Table 2). The dry matter (DM) content of the harvested alfalfa was set to 35\% (Møller et al., 2005). It was assumed that alfalfa is ensiled prior to its conversion to lactic acid, as ensiling is preferable for lactic acid production. Ensiling also favours biomass storage without burden of drying the fresh green biomasses. It is also useful to ensure a year-round supply of biomass to a biorefinery plant (Ambye-J ensen et al., 2013). 
The mass transformation of carbohydrate and CP contained in the fresh biomass to lactic acid and feed protein respectively (Fig. 2) were partly based on O’Keeffe et al. (2011) (Table 2), and are detailed in SI-6 (Fig. S-6.1). Unlike to O’Keeffe et al. (2011), the current study assumed enzymatic hydrolysis to hydrolyse the press cake. Hydrolysis facilitates for an enhanced availability of glucose from the carbohydrate contained in the pretreated biomass (Alvira et al., 2010). This is useful to increase the yield of biobased lactic acid than only depending on the juice fractions (see section 2.6.1).

Table 2. Basic assumptions on the parameters considered in the inventory analysis.

\subsection{Life cycle inventory for the biomass production}

Within CLCA approach, consequences of the straw removal process (see section 2.3.1) were calculated for 1 ton ( $\mathrm{t}$ ) straw (85\% DM). The consequences, in terms of emission due to SOC change amounted to $143 \mathrm{~kg} \mathrm{CO}_{2}$ eq per t straw removed (Parajuli et al., 2014). Additional processes, such as baling, loading and the transport of straw to biorefinery plant were also considered to calculate the total impact of utilizing the removed straw. Diesel consumed during baling, loading and transporting the biomass (Table3) was based on the study, reported by Dalgaard et al. (2001). Likewise, necessary data for the alfalfa production were derived from Parajuli et al. (2017), and is reported in Table S-1.1 in SI-1.

Within ALCA approach, environmental impacts of producing straw from winter wheat was obtained from Parajuli et al. (2016); and for alfalfa it was adapted from Parajuli et al. (2017).

A distance of $200 \mathrm{~km}$ (Bentsen et al., 2009) single-trip was assumed for the transportation of both biomasses to the biorefinery plant.

\subsection{Life cycle inventory for biomass conversion}

\subsubsection{Standalone systems}

System A: The basic data related to biomass production, particularly emissions are shown in Table 3. Likewise, energy and material inputs assumed for the biomass processing are also given in Table 3. Key stages for the straw conversion to bioethanol included: (i) pretreatment of the straw, (ii) hydrolysis, (iii) fermentation, and (iv) recovery of the products. Hydrothermal pretreatment was assumed, as it is suitable to breakdown lignocellulosic structures of straw into reactive cellulosic intermediates (Galbe et al., 2007). In the current study, after the hydrolysis process, the mass transformation was assumed to follow a simultaneous saccharification and fermentation process and then the distillation process (Galbe et al., 2007) . The total energy input, excluding the use of coproduced energy was calculated as $0.98 \mathrm{MJ}$ per $\mathrm{MJ}_{\mathrm{EtOH}}$ (Bentsen et al., 2009), which was close to the values reported in the studies, e.g. Pimentel and Patzek (2005) and Wang (2001). Likewise, the direct primary energy input to the biorefinery plant (excluding the energy input to the biogas and lignin fired combined heat and power (CHP) plants was calculated as $26 \mathrm{MJ}$ per $\mathrm{kg}$ ethanol production, which was also comparable with the range reported for cellulosic ethanol plant 
(approximately 5-25 MJ per kg), as reported in the various studies (Kim and Dale, 2005; Luo et al., 2009b; Pimentel and Patzek, 2005; Sheehan et al., 2003). The process-wise contribution to the total energy input was assumed as: pretreatment and hydrolysis (70\%), saccharification and fermentation (3\%), product-recovery (24\%). Generally, by-product recovery (including pelletization of lignin) contributes about $10 \%$ of the primary energy input (Luo et al., 2009a).

Potassium chloride $(\mathrm{KCl})$ produced during the pretreatment of straw was considered to be recovered as fertilizer (Larsen et al., 2012) (Table 3) (Fig. 1). The recovery rate of $\mathrm{KCl}$ was set to 90\%, and equivalent amount of potassium was estimated using the ratio of molar weight of $\mathrm{K}$ to $\mathrm{KCl}$. The solid particle (lignin) collected from the distillation column was assumed to be fired in a CHP plant (Eriksson and Kjellström, 2010; Nunes et al., 2014). The CHP plant was also assumed to be developed within the same location where biorefinery is assumed to be operated, in order to minimize the logistic emissions. The liquid particles from the stillage and hydrolysate were considered as substrates to produce biogas (SI-2 and SI-5). The energy balance showed that energy recovery potential both from the biogas and lignin-fuelled CHP plants was able to fulfil $45 \%$ and $181 \%$ of the thermal and electric energy demand of the bioethanol system; hence heat energy required was on deficit (Table 5).

Table 3. Primary input and output of materials related to the conversion of 1 t straw (with $85 \%$ DM) to bioethanol (System A), all data are per 1 t straw.

System B: Table 4 summarizes the input-output flow of the materials and energy considered in System B. The mass and energy flows for system B were calculated partly following the studies reported by O'Keeffe et al. (2011) and Kamm et al. (2009). In the current study, lactic acid was assumed to be produced from the (i) juice fraction and (ii) glucose fractions produced from press cake. The glucose fraction was estimated from the hydrolysed mass of the press cake (i.e. fiber portion) (detailed in SI-6). Sugar fractions in the press cake was assumed to be 33\% (Cybulska et al., 2010) of the total fiber fractions (on DM basis) (Fig S-6.1). The rest of the fiber particle contained in the press cake was considered to be suitable as livestock feed (Kamm et al., 2009), hereafter referred as "fodder silage" (Table 4). Glucose produced after the enzymatic hydrolysis was thus considered for the fermentation process. Extraction efficiency of crude lactic acid contained in the press juice (i.e. $26 \mathrm{~kg}$ lactic acid per t DM juice) to produce the final product was set to 70\% (O'Keeffe et al., 2011), yielding $18 \mathrm{~kg} \mathrm{DM}$ of biobased lactic acid. Likewise, the glucose to lactic acid conversion factor was set to $79 \%$ (Doran-Peterson et al., 2008), yielding 72 kg be contained in the solid fractions of hydrolysed particles (see Fig S-6.1). The total production of biobased lactic acid was thus estimated to be $89 \mathrm{~kg}$ DM (Table 4, SI-6). The calculated yield of biobased lactic acid was close to the estimates reported in Kamm et al. (2009) (approx. $83 \mathrm{~kg}$ per $\mathrm{t}$ DM of the grass silage under similar DM content of the raw biomass). Detailed process, including the recovery of biobased lactic acid is elaborated in SI-6. Furthermore, liquid residue produced from the processing of biomass was considered as substrate for biogas production, which was $6 \%$ of the 
mass of decanted juice (Table 2), and was close to the amount reported in Kamm et al. (2009). Energy consumption for these processes is summarized in Table S-3.1.

Table 4. Input-output of materials for the conversion of 1t DM alfalfa to biobased lactic acid (system B), all data are per $t$ DM of alfalfa.

\subsubsection{Integrated system}

System C: Mass and energy flows during the combined production of both bioethanol and lactic acid in system C are detailed in SI-4, Fig. S-4.1. System C was designed by assembling the two standalone systems. During the integration, the energy, which was reported to be deficit in the standalone systems, was partially covered by exchanging from one system to another (Table 5). The produced biobased products were the same, as collectively described for system A and system B. The difference in the systems was in the form of surplus electricity, and it was $1.23 \mathrm{GJ}$ e, estimated from the system integration, but the system was still deficit in term of heat energy (Table 5).

2.7 Life cycle inventory for the secondary processing

2.7.1 Energy balancing for the biorefinery systems

The secondary processing of biomasses included handling of the residual products. For system A, lignin was assumed as a biofuel for the combustion in a CHP plant producing heat and power. Emissions from the combustion was assumed similar to Danish coal based CHP plants (Danish Energy Agency, 2012). Likewise, $\mathrm{C}_{5}$ molasses and the liquid residues were assumed to be collected from system A and were considered for the conversion to biogas. The mass of the substrates for biogas conversion in system A was calculated based on the studies reported by Bentsen et al. (2009) and Kaparaju et al. (2009). In the case of system B, the handling of residual stream was the conversion of decanted liquid residues to biogas production. The fermentable substrate for system $B$ was based on the proportion of volatile substance (VS) in the decanted press juice (O'Keeffe et al., 2011) (Table 2) (see SI-6, Fig. S-6.1). For the both standalone systems, total methane yield was calculated after Pugesgaard et al. (2013) (see detail in the SI-2). The energy balance of the entire systems is shown in Table 5; whereas specific input to system A and system B is shown in Table 3 and Table 4.

Table 5: Energy balance calculated for the biorefinery plants. The balance accounted all useful energy consumption within the biorefinery systems. 


\subsubsection{Nutrient recovery}

Recoverable nutrients from the biogas digestate was calculated in the form of total N, P and Kcontent (Drosg et al., 2015) (Table 2). The total mass of digestate was calculated after subtracting the losses. Loss of total solids (TS) content was assumed as 50\% of the available mass generated after the anaerobic digestion compared to the initial pre-digester level (Drosg et al., 2015; Lebuf et al., 2013). About $40 \%$ of the recoverable $\mathrm{N}$ and $100 \%$ each for $\mathrm{P}$ and $\mathrm{K}$ was assumed to substitute the equivalent amount of synthetic fertilizer (Hansen et al., 2006). Likewise, recovery of K from KCL was also considered for System A (Table 3). The recovery of nutrients in system $\mathrm{C}$ was thus of the total nutrients calculated for the two standalone systems. The recovered nutrients contained in the digestate were assumed to be transported back to the farmers' field, considering similar distance of transporting the biomass to the biorefinery plant.

\subsection{Assessments on indirect land use change effects}

iLUC was considered as the upstream consequences of occupying a productive land in Denmark during the biomass production. Within CLCA, consequently induced GHG emissions was calculated covering both, (i) upstream consequences of occupying a productive land in Denmark to produce alfalfa and (ii) avoided iLUC assumed to be occurring due to the substitution of the alternative agricultural products, assumed to be displaced by the biobased products. For the first element, iLUC factor of $1.73 \mathrm{t} \mathrm{CO}_{2} \mathrm{eq}$ ha-1 $\mathrm{y}^{-1}$ was considered (Schmidt and Muños, 2014). For the second element, the avoided iLUC was calculated based on the equivalent amount of feed products displaced due to the production of feed protein and fodder silage from system B (Fig. 2) and system C (Fig. 3) (see Table 2 for the composition of protein and energy feed). Feed protein produced from system B and system $C$ thus resulted to avoid 0.04 and 0.1 ha of land, which was assumed otherwise would be occupied elsewhere for the production of corresponding marginal crops (i.e. spring barely and soymeal respectively) to maintain the equivalent demand (Fig. 2 and Fig. 3) (Dalgaard et al., 2007). GHG emission avoided due to such avoidance of the land occupation was based on the carbon footprint results of barley and soybean, as suggested in (Dalgaard et al., 2007). In addition, while calculating avoided iLUC, other chain effects in the form of so-called "soybean loop" (Dalgaard et al., 2007) was also considered. The chain effect was assumed to initiate with an argument that due to co-produced feed protein less soybean meal will be produced. Hence, a reduction in the production of soybean and also soy oil will occur (Schmidt and Brandao, 2013), and such loss is compensated by increasing the production of marginal oil, which may turned out to be palm oil, and so on. The induced GHG emissions from the "soybean loop" was calculated based on the estimates reported in Dalgaard et al. (2007), but was in an opposite analogy, as the current study deals for a reduction in the demand of soymeal due to co-produced feed protein (Figs. 2-3). The study hence had following key assumptions:

- $1 \mathrm{~kg}$ decrease of soybean meal would decrease the production of soybean to $1.005 \mathrm{~kg}$. 
- It resulted to compensate the demand of soy oil by palm oil, and the added burden would be in the form of producing $0.86 \mathrm{~kg}$ of fresh fruit bunches and avoiding $0.012 \mathrm{~kg}$ of spring barley. GHG emissions related to fresh fruit bunches and spring barely covered in the "soybean loop" were based on the same study (Dalgaard et al., 2007), which were respectively, 177 and $671 \mathrm{~kg} \mathrm{CO} 2$ per $\mathrm{t}$ product.

Considering the above effects, the net iLUC in terms of GHG emissions was calculated to be $1.6 \mathrm{t} \mathrm{CO}_{2}$ ha-1 $\mathrm{y}^{-1}$ during the production of $89 \mathrm{~kg}_{\mathrm{LA}}$ (co-producing $34 \mathrm{~kg}$ of feed protein and $261 \mathrm{~kg}$ DM fibers) and other non-agricultural products. The result was used only for system B and system C, as they involved the production of alfalfa and had the co-products, which were assumed to be displacing the marginal feed products (Table 1). It should be noted that within CLCA approach, straw was treated with no iLUC effect (Schmidt and Brandao, 2013), provided that it depends on theassumed reference situation (see section 5.3.2).

Within ALCA approach, the iLUC factor was assumed to be $2.7 \mathrm{t} \mathrm{CO}_{2} \mathrm{ha}^{-1} \mathrm{y}^{-1}$, which was amortized for 100 years after the value (270 t CO$_{2}$ eq ha-1), as reported in Fritsche et al. (2010). A different iLUC factor was considered within this approach than that of in CLCA approach, and was mainly to avoid the methodological collision, as can be caused by summing average and marginal effects (Creutzig et al., 2012). In the current study, within ALCA approach, the iLUC factor considered was based on Fritsche et al. (2010) and it was argued that growing bioenergy crops in 1 ha of land would displace 1 ha of the previous production. They estimated the change in the production based on the exported products relevant for the bioenergy sector, e.g. soy and palm oil (Fritsche et al., 2010). Uncertainties, with regard to the approach considered during the inclusion of iLUC in the assessment of net GHG emissions are further discussed in section 5.3.2.

\subsection{Sensitivity analysis}

Sensitivity analysis is aimed to cover the potential uncertainties in the results due to different assumptions and the process configurations, as discussed below.

\subsubsection{Avoided products scenario}

Marginal electricity: The sensitivity analysis included natural gas as a marginal fuel for electricity generation (Mathiesen et al., 2009).

Marginal energy-feed: Grass silage was assumed as marginal energy feed in the sensitivity analysis. It was assumed that the fibers obtained from system B can meet the equivalent feed energy demand, which is conventionally available from grasses to livestocks. Furthermore, in the current study, since alfalfa was considered as the principal raw material, the conventional way of directly utilizing the forage, as a source of animal feed can be partially changed. The change was assumed to be covered from the supply of fodder silage, co-produced from systems C and B (Figs.2-3; Table 1). In this scenario, the supply of biomass was assumed to be from a Danish farm. 
Utilization of $\mathrm{C}_{5}$ sugar to boost bioethanol yield: In the basic scenario, only the fermentation of $\mathrm{C}_{6}$ sugars was assumed to produce bioethanol, and the $\mathrm{C}_{5}$ sugar contained in the molasses was used during the biogas conversion. Alternatively, in the sensitivity analysis, a simultaneous conversion of both $\mathrm{C}_{6}$ and $\mathrm{C}_{5}$ sugars was considered to boost the bioethanol yield. This was in accordance to the claims that bioethanol yield can be increased if both $\mathrm{C}_{6}$ and $\mathrm{C}_{5}$ sugars are simultaneously fermented with the use of an advanced yeast technology (Inbicon, 2013; Losordo et al., 2016). For this consideration hemicellulose (i.e. 0.057 t DM per t DM straw, see SI-5, Fig. S-5.1), which was estimated to be in the hydrolysate, was considered as the intermediate raw material for the fermentation process. The calculated increase in the bioethanol yield was $14 \%$ compared to the yield reported in the basic scenario (Table 3). For the estimation, only $88 \%$ of the sugar contained in the hydrolysate was assumed to be utilized, and thereby yielding $0.38 \mathrm{~g}$ bioethanol per gram sugar converted (Biswas et al., 2013). Hemicellulose, since was assumed to be used as intermediate raw material, the consequences was in the form of a reduced mass of substrate available for biogas conversion. Eventually, it resulted to a reduction in the net energy production. The calculated reduction in the electricity production was $18 \%$ compared to the basic scenario. The calculated values for the increase in the bioethanol yield and the reduction in the electricity production were close to the range of $20 \%$ to $31 \%$ and from $12 \%$ to $37 \%$ respectively (Losordo et al., 2016). During the environmental evaluations, the added function to system $\mathrm{B}$, as discussed in section 2.2 was also adjusted accordingly along with the varied bioethanol yield.

Varying the yield of biobased lactic acid production: The yield of biobased lactic acid was varied from $-10 \%$ to $+10 \%$ compared to theyield considered in the basic scenario (Table 4 ). Thelower range was set approximately to match with theyield reported in Kamm et al. (2009). During the evaluation, such changes in the yield were also considered on the part of the added function assumed entering to system A (section 2.1).

\subsubsection{Calculation of energy and mass based allocation factors}

In this case, mass and energy-based allocation method was considered for calculating the allocation factors (parameters considered for the estimation is shown in Table 2).

\section{Results}

Table 6 shows the results for the selected environmental impact categories. Both net and gross values of the impacts are presented. Net and gross values are with and without avoided impacts respectively.

\subsection{Overview of the standalone and integrated systems}

The characterized results obtained within CLCA and ALCA approach for the selected biobased products are shown in Table 6. The results revealed that compared to system A and system B, system C performed better in most of the environmental impact categories. Within CLCA and ALCA approach, net GWP 100 calculated per FU for system C were 58\% and 20\% lower than system A (Table 
6). Within CLCA approach, when iLUC was considered net GWP ${ }_{100}$ per FU for system B and system

C was increased by 39\% and 84\% compared to the results without iLUC (Table 6). Within ALCA approach, net GWP $\mathrm{F}_{100}$ (with iLUC) was higher by $2 \%, 7 \%$ and $12 \%$, respectively in system A, system $\mathrm{B}$ and system $\mathrm{C}$.

With regard to eutrophication potential, within CLCA approach the impact for system C was 86\% lower compared to system A, whilst, it was 6\% higher within ALCA approach (Table 6). Likewise, NRE use calculated for system $C$ was $66 \%$ and $32 \%$ lower than system A, respectively within CLCA and ALCA approach. On contrary to other impact categories, for both approaches, agricultural land occupation for system $\mathrm{C}$ was higher than system $\mathrm{A}$ (Table 6).

With regard to the comparison between system $C$ and system B, similar characteristics were found; revealing better environmental performance for system $\mathrm{C}$. Results showed that within CLCA and ALCA approach, net GWP 100 was respectively, 86\% and 31\% lower in system C than system B, followed by EP (101\% and 63\%), NRE use (97\% and 52\%\%) and ALO (94\% and 38\%) (Table 6).

Table 6. Environmental impacts of producing bioethanol and lactic acid from the standalone plants and from system $\mathrm{C}$ (FU is " $1 \mathrm{MJ} \mathrm{EtOH}+1 \mathrm{~kg}_{\mathrm{LA}}$ "). Negative values indicate the environmental impact abatement potentials.

\subsection{Comparison of the systems based on CLCA and ALCA approach}

Environmental impacts computed using CLCA and ALCA approach were compared for each biorefinery system under following criteria.

\subsubsection{Environmental differences}

Within CLCA approach, net GWP 100 calculated for systems A, B and C were, respectively 97\%, 91\% and $98 \%$ lower than that of the ALCA approach. In the similar order of biorefinery systems, EP was respectively, 97\%, 110\% and 100\% lower in CLCA compared to ALCA approach, NRE use (97\%, 78\% and 99\% respectively), ALO (99\%, 77\% and 98\%) (Table 6). These revealed that regardless of the approach used, the relative differences in the impact categories in each individual system consistently showed the similar impact pattern.

\subsubsection{Hotspots identification}

Contribution from the biomass production process:

Fig 4 shows the contribution of different value chains of biorefinery in the standalone and integrated systems. Within CLCA and ALCA approach, the related added function contributed 36\% and 30\% respectively of the gross GHG emissions and it was 38\% and $21 \%$ in system B (Fig 4 and Table 6). Within CLCA and ALCA approach, the contribution from the biomass production was respectively, $16 \%$ and $17 \%$ of the gross $\mathrm{GWP}_{100}$ obtained in system A. The same value chain contributed $57 \%$ and $55 \%$ in system B, and in system Cit was $46 \%$ and $60 \%$, respectively within CLCA and ALCA approach (Fig. 4). Related emissions related to the biomass production, e.g. $\mathrm{N}_{2} \mathrm{O}$ and emission due to SOC 
change are shown in Tables 3-4. Within CLCA approach, emission due to SOC change contributed $14 \%$ of gross $\mathrm{GWP}_{100}$ (system A). Likewise, SOC change related to the production of alfalfa mitigated $0.32 \%$ of the gross $\mathrm{GWP}_{100}$ obtained for system B (i.e. $-0.02 \mathrm{~kg} \mathrm{CO}_{2}$ eq per FU). In system $\mathrm{C}$, GHG emissions due to net SOC change (i.e. considering both the loss of SOC during the straw removal and the sequestration during alfalfa production) contributed $11 \%$ of the gross $\mathrm{GWP}_{100}$. Despite straw removal resulted to a loss in SOC, consequently the avoided $\mathrm{N}_{2} \mathrm{O}$ emissions mitigated $2 \%$ of the gross $\mathrm{GWP}_{100}$ (in system A). Likewise, $\mathrm{N}_{2} \mathrm{O}$ emissions estimated for the alfalfa production, however, added $0.11 \%$ of the gross impact obtained for system $\mathrm{B}$. Whilst, since net $\mathrm{N}_{2} \mathrm{O}$ emissions was negative (i.e. was avoided) in system $C$, it resulted to mitigate $0.3 \%$ of its gross impact. On contrary, within ALCA approach, mitigation of GHG emissions due to SOC change was $6 \%$ of the gross $\mathrm{GWP}_{100}$ for system A. Likewise, it mitigated $0.3 \%$ and $10 \%$ of the gross GHG emissions, respectively obtained for system $B$ and system C. In the same manner, contribution to the gross $\mathrm{GHG}$ due to $\mathrm{N}_{2} \mathrm{O}$ emissions was $7 \%$ in system $\mathrm{A}$, and was respectively, $0.1 \%$ and $8.3 \%$ in system $\mathrm{B}$ and system C.

With regard to EP, in system A the contribution to the gross impact was $7 \%$ and $25 \%$ computed within CLCA and ALCA approach respectively. It was 77\% and 43\% of the obtained impact for system B, and in system C (47\% and 914\%) (Fig. 4).

In the same manner, the same value chain covered $2 \%$ and $20 \%$ of the gross NRE use obtained within CLCA and ALCA approach respectively. It should be noted that within CLCA approach, straw accounted only energy used for baling and transporting the removed straw (Table 3), whilst within ALCA approach, diesel consumed during winter wheat production was economically allocated to straw. In system B, the biomass production process contributed $66 \%$ and $64 \%$ of the gross impact calculated within CLCA and ALCA approach respectively; and for system C (62\% and 97\%) (Fig. 4). With regard to the contribution to the gross ALO, the contribution in the same order of the approach used, was $0.02 \%$ and 74\% (system A); system B (103\% and 79\%) and system C (87\% and 99\%) (Fig. 4).

Major differences in the relative contributions with respect to the gross impact obtained for system A and system $\mathrm{C}$, as discussed above was mainly due to assumptions made on the process of harnessing straw in the considered LCA approaches. The contribution pattern in both approach, however, in vast majority of the cases were consistent and it also revealed that biomass production was one of the principal contributors to most of the selected impact categories. 
Contribution due to material inputs and biorefining processes

The contribution due to material inputs and the processing of biomass in system A were $48 \%$ and $53 \%$ of the gross GWP $_{100}$ obtained within CLCA and ALCA approach respectively, in system B it was $4 \%$ and $24 \%$, and system C (54\% and 40\%) (Fig. 4). Likewise, the contribution to the gross EP from the stated process was $72 \%$ and $58 \%$ (system A), respectively computed within CLCA and ALCA approach. In system B, it was $2 \%$ and $28 \%$, and in system Cit was $53 \%$ and $6 \%$ of the respective gross impacts (Fig 4). The contribution to EP in system $\mathrm{C}$ though was significantly different in relative terms, but the absolute values were close within both approaches (e.g. 0.0002 and $0.0003 \mathrm{~kg} \mathrm{PO}_{4}$ per FU).

With regard to the contribution to the gross NRE use, it was $29 \%$ and $32 \%$ of the gross impact obtained for system A, as obtained using CLCA and ALCA approach respectively (Fig. 4 and Table 6). For the same impact category, in system B, it was $0.8 \%$ and $20 \%$ of the gross impact obtained within CLCA and ALCA approach respectively; and for system C (38\% and 3\%). Contribution to the gross ALO, in the same order was $102 \%$ and $26 \%$ (system A); system B constituted with $0.3 \%$ and $6 \%$, and in system $\mathrm{C}$ it was $13 \%$ and $1 \%$ (Fig. 4 ).

Fig 4. Contribution of processes involved in the entire biobased products chains.

\subsection{Co-products handling and the environmental impacts}

Within CLCA approach, the selected biobased products were credited substantially in terms of their environmental footprints (Fig. 4). Likewise, within ALCA approach, burdens were significantly shared by the co-products with respect to the environmental cost they owe during the operation of biorefinery systems (Table 7). The results showed that within CLCA approach the co-produced products, such as electricity, fodder silage (fibers) and feed protein contributed the most to the net avoided impacts. Likewise, they also shared the most of the burdens within ALCA approach, after the impact was attributed to the main products. Example, in system C, the results on $\mathrm{GWP}_{100}$ showed that electricity, fodder silage, recovered nutrients and feed protein contributed $55 \%, 28 \%, 12 \%$ and $2 \%$ of the net avoided impact (Table 7). Likewise, within ALCA approach, electricity and feed protein had GWP 100 as 0.55 and $0.44 \mathrm{~kg} \mathrm{CO}_{2}$ eq per FU (Table 7).

Table 7. Contribution patterns of the co-products for avoiding and sharing the environmental impacts within CLCA and ALCA approach. Units per FU in each system are: net $\mathrm{GWP}_{100}=\mathrm{kg} \mathrm{CO} 2 \mathrm{eq}$, $\mathrm{EP}=\mathrm{kg} \mathrm{PO}_{4} \mathrm{eq}$, $\mathrm{NRE}$ use $=\mathrm{MJ}$ eq , and $\mathrm{ALO}=\mathrm{m}^{2}$.

\section{Results of the sensitivity analysis}

\subsection{Natural gas as a fuel source for marginal electricity production}

Assuming natural gas as the marginal fuel for electricity production, net GHG emissions calculated for system A, system B, and system C was respectively, 10\%, 71\%, and 51\% higher compared to the basic scenario (Table 6). On contrary, net NRE use obtained for all the systems ranged 1-5\% lower than the basic scenario (Table 8). Higher net $\mathrm{GWP}_{100}$ in the case of selecting natural gas as the 
marginal fuel for electricity production was due to less environmental impact being displaced compared to coal. In the same manner, compared to coal, fossil fuel intensity is lower in conversion cycle of natural gas to energy.

\subsection{Grass silage as an alternative source of animal feed}

It resulted to increase both $\mathrm{GWP}_{100}$ and NRE use for system B and system C significantly compared to the basic scenario (Table 8). This was as a result of lower avoided impact compared to the basic scenario (Tables 6-7).

\subsection{Variations in the yields of biobased products}

With the assumption on the recirculation of $\mathrm{C}_{5}$ sugars, bioethanol yield was increased by $14 \%$. On such, GWP 100 obtained per FU for system A and system C was lower by $12 \%-15 \%$ compared to the basic scenario (Table 6). Similarly, compared to the basic scenario, NRE use was reduced by $12-32 \%$ in the designed biorefinery systems (Table 8).

Likewise, with a $10 \%$ increase or decrease in the biobased lactic acid, there were no significant changes in the impact for system A, but the impact of systems B and C were affected (Table 8). This revealed that the designed system was more sensitive to the bioethanol conversion processes and its yield. Likewise, the cost of importing the conventional lactic acid would bear a higher impact, if standalone systems are to be promoted instead of system C.

Table 8. Results obtained from the sensitivity analysis. Units per FU of each system are: net GWP 100 $=\mathrm{kg} \mathrm{CO} 2$ eq and $\mathrm{NRE}$ use $=\mathrm{MJ}$ eq.

\subsection{Variations in the allocation factors}

The allocation factor computed for bioethanol within system A and system C, as was considered in the basic scenario was $46 \%$ and $39 \%$ respectively (section 2.3.2). Likewise, the allocation factor for biobased lactic acid, as considered in the basic scenario was $37 \%$ and $32 \%$ in system B and system C respectively. Uncertainties with the allocation factors computed using economic allocation method may prevail due to surges in the future prices of biobased products. Furthermore, using the energetic allocation method, the allocation factor obtained for bioethanol was $87 \%$ in system A and it was $68 \%$ in system $C$, which was after covering the energy values of biofuel, electricity and biobased lactic acid (Table 2). Likewise, using mass-based allocation method, allocation factor for bioethanol was 94\% and 31\% respectively, in system A and system C. Within the same method, biobased lactic acid resulted with allocation factor of $15 \%$ in system B and system C. It revealed that allocation factors vary as per the types of products and the determining properties (e.g. market price, energy and other utilities) of the products. The drawback of using mass and energy-based allocation method was however related to their limitation for not covering products with different physical units and functions. Example, energetic products like fuel, electricity are ignored when mass allocation is considered; and likewise biobased lactic acid, feed protein and fodder silage are potentially ignored if energetic-allocation is considered. Similar issues are also highlighted in other LCA studies, e.g. in 
Singh et al. (2010), whenever a production system involve different products. This is however guided by the scope and purposes of the assessment, e.g whether it aims for examining the internal improvements in the manufacturing process, and/ or, for the external communication to the market

4 (Svanes et al., 2011).

\section{Discussions}

Discussions are made firstly by comparing the results calculated for the individual product with the other related studies and also outlining the research perspectives. To calculate the environmental impacts of the individual product, the contribution of the added functions (Fig. 4) was subtracted from the net impacts (Table 6). This was assumed to be similar to the cases of assessing the impact of separately producing bioethanol and biobased lactic acid, as from system A and system B.

\subsection{Bioethanol production}

On a product basis, the obtained results were found comparable with other studies. Example, if contribution of the added function was neglected, net GHG emissions for producing bioethanol would be $0.08 \mathrm{~kg} \mathrm{CO} 2$ per $\mathrm{MJ}_{\mathrm{EtOH}}$ (or $2.3 \mathrm{~kg} \mathrm{CO} 2$ eq per $\mathrm{kg}_{\mathrm{EtOH}}$ ). The contribution due to added function in this case was $36 \%$ to the gross $\mathrm{GWP}_{100}$ (Fig. 4). The result obtained for bioethanol was within the range, as reported for the lignocellulosic bioethanol (-0.007 to $3.9 \mathrm{~kg} \mathrm{CO}_{2}$ per $\left.\mathrm{kg}_{\mathrm{EtOH}}\right)$ (Borrion et al., 2012; Degussa et al., 2006; González-García et al., 2012; Morales et al., 2015; Muñoz et al., 2013; Wang et al., 2013). The variations on the impacts in these studies were mainly due to: different biomass feedstocks and methods considered in the evaluation. Following the similar assumption made for neglecting the impact of theadded function, within CLCA and ALCA approach, the biomass production contributed $24-25 \%$ of the gross GWP $_{100}$, which was reported to be $30-60 \%$ inWang et al. (2013). The contribution from the enzyme production as obtained for system A was $29 \%$ of gross $\mathrm{GWP}_{100}$ (i.e. $32 \%$ of net $\mathrm{GWP}_{100}$ ), which was reported $40 \%-60 \%$ of the net impact in Wang et al. (2013). Likewise, net NRE use obtained for bioethanol (system A) would was 0.49-0.69 MJ eq per $\mathrm{MJ}_{\mathrm{EtOH}}$ which was reported ranging from 0.1 to $0.8 \mathrm{MJ} / \mathrm{MJ}_{\mathrm{EtOH}}$ (García et al., 2011; Morales et al., 2015).

In the current study, the net savings, in terms of GHG emissions due to bioethanol production was $74 \%$ compared to petrol. GHG savings for an identical biorefinery plant was in the range of $44 \%$ to 89\% (Cherubini and Ulgiati, 2010; Michael et al., 2012; Wang et al., 2013), and the results were varying accordingly with different biomasses and assumptions made on the system boundaries. Likewise, the net savings, in terms of NRE use due to bioethanol production was 91\% compared to petrol. For corn based bioethanol production, the savings on NRE use through the utilization of bioethanol (E-85) was 95\% and was 102\% for E-100 (Sheehan et al., 2003).

Under the most favourable conditions, enzyme dosage can be reduced by 30-50\% through recovery process (Ramos et al., 1993), and without compromising the glucose yields (Weiss et al., 2013). The significance of such prospect can be seen clearly credited to bioethanol, as contribution of enzyme to the environmental impacts (as discussed earlier) can be minimized. Likewise, the current 
development in the enzymes production is also expected to lower the GHG profile by 50-70\% compared to Cellic CTec3 (Kløverpris, J.H. 2016.pers.comm.). This can also be regarded as another potential opportunity to further lower the environmental footprints of lignocellulosic bioethanol.

\subsection{Biobased lactic acid production}

If the added function was neglected in system B, within CLCA and ALCA approach, the obtained net $\mathrm{GWP}_{100}$ for the production of $1 \mathrm{~kg}$ biobased lactic acid was 0.24 and $3.08 \mathrm{~kg} \mathrm{CO}_{2}$ eq respectively. Within the approach of system expansion, results on GHG emissions were found ranging from -0.6 to $2.7 \mathrm{~kg} \mathrm{CO} 2$ eq per $\mathrm{kg}_{\mathrm{LA}}$ (Degussa et al., 2006; European Commission, 2016). Likewise, within economic allocation method, Daful et al. (2016) reported that GWP $\mathrm{G}_{100}$ for the biobased lactic acid production was $4.34 \mathrm{~kg} \mathrm{CO} 2 \mathrm{eq} / \mathrm{kg}_{\mathrm{LA}}$. With regard to NRE use, it ranged from 3.5 to $20 \mathrm{MJ} / \mathrm{kg}_{\mathrm{LA}}$ (on a cradle to cradle basis), and 32-43 MJ / kg LA (on a cradle to factory gate basis) (Degussa et al., 2006). In another study, European Commission (2016) reported that NRE use ranged from 9 to 37 MJ per kgLA. In the current study, without the added function to system B, net NRE use would be 10 and 50 $\mathrm{MJ} / \mathrm{kg}_{\mathrm{LA}}$, within CLCA and ALCA approach respectively. The minor differences in the results with the reported studies, e.g. European Commission (2016) were partly due to different: feedstocks (corn, sugarcane and corn stover) and the assumptions made on the evaluation approaches (system expansion and economic allocation, indicating the lower and the higher values respectively for the reported impact). Furthermore, in the current study, alfalfa, since is nitrogen fixing plant, application of synthetic $\mathrm{N}$-fertilizer was not considered (SEGES, 2010). This also resulted to reduce GHG emission, particularly during the fertilizer production and theapplication (Parajuli et al., 2017).

Upon the comparison with the conventional lactic acid, the net savings in terms of GHG emissions due to the production of biobased lactic acid was $97 \%$ and $36 \%$, respectively within CLCA and ALCA approach. Savings in terms of NRE use was 88\% and 30\% compared to conventional lactic acid. Hence, both approaches yielded with the same conclusion in terms of lower environmental footprints compared to their conventional counterparts.

\subsection{Methodological dilemma and persepctives}

\subsubsection{Consequences of straw removal}

In the current study, the consequence of removing straw, in terms of emissions due to SOC change was calculated as $143 \mathrm{~kg} \mathrm{CO}$ eq per $\mathrm{t}(85 \% \mathrm{DM})$. With regard to the removed mass of straw, it was $31 \%$ of the total straw yield (Parajuli et al., 2016). The impact of such can be neglected if the concept of "sustainable rate of residues recovery" is considered. Sustainable recovery rate was suggested to be within the range of $33 \%$ and $50 \%$, and is also argued for a nominal effect on SOC change (Scarlat et al., 2010; Spöttle et al., 2013). Scarlat et al. (2010), while suggesting 40\% as the recovery rate; also argued that it can be sustainably removed from the field once every 2.5 years on average. This may stress to examine the consequences to an agro-ecosystem when large and commercial scale biorefineries, primarily depending on straw are to be developed, keeping in mind that there are other sectors demanding the same biomass (Gylling et al., 2013). Likewise, maintaining SOC, even 
removing straw was argued could be only possible if the grain yield exceeds certain level (J ohnson et al., 2006; Tarkalson et al., 2009). Considering the widerange of the applications of straw in different sector (Gylling et al., 2013), it might be relevant to assess the consequences of using straw with respect to a reference situation that it may affect.

\subsection{2 iLUC and the system boundaries}

With regard to the impact induced due to iLUC, there are some studies urging for more scientifically robust and consistent way of assessing the impact, if it should be included in carbon footprint assessments (Finkbeiner, 2013). Furthermore, Langeveld et al. (2014) suggested that the evaluation should be enriched by incorporating more information on land use changes and examine influences of local cropping patterns, as well as differences in current and potential productivities in different agro-ecologies and farming systems. It was further supported by another critic, "given that there is no accepted approach to estimate the global effects of biofuel policy on land-use change, it is critical to assess the actual effects of policies through careful analysis and interpretation of empirical data" (Kline et al., 2011). Despite the stated critics, a general consensus, particularly on the prevalence of effect was also found (Gawel and Ludwig, 2011; Kløverpris and Mueller, 2013). Moreover, one of the major challenges and debated issue is on the methods to quantify the induced GHG emissions and the uncertainties associated with it (Broch et al., 2013; Di Lucia et al., 2012; Warner et al., 2014). Several methods have quantified the impact of iLUC, e.g. in Audsley et al. (2009), Cederberg et al. (2011) and Schmidt et al. (2015). A generic iLUC factor of 1.73 t CO2 eq ha-1 $\mathrm{y}^{-1}$ (Schmidt and Muños, 2014) was used in this study. Moreover, the iLUC factor suggested in other studies are: $1.43 \mathrm{t} \mathrm{CO}_{2} \mathrm{eq}$ ha- $\mathrm{y}^{-1}$ (Audsley et al., 2009) and $1.9 \mathrm{t} \mathrm{CO} 2$ eq ha-1 $\mathrm{y}^{-1}$ was suggested for the world average arable land (Schmidt and Muños, 2014). Likewise, iLUC factors were also reported varying with the assumptions on the types of the occupied land, e.g. for soy meal production it ranged from 1.5 to $10 \mathrm{t} \mathrm{CO}_{2} \mathrm{ha}^{-1} \mathrm{y}^{-1}$. The highest value was reported if the conversion takes place in forest land and the lowest was in grassland (Leip et al., 2010). These showed that the results on GHG emissions of the biobased products, including iLUC then would have higher degree of variations based on the factors assumed in the calculation.

Likewise, in the current study through "soybean loop", we assumed that during the avoidance of soymeal the effect would be on the production of soy oil, and on such marginal oil has to compensate the demand. It was assumed that palm oil was the marginal oil, however it is difficult to be certain which of the oil types (palm or rape seed) would be the marginal source (Dalgaard et al., 2007). Likewise, within CLCA approach, the conversion of straw to bioethanol was regarded without iLUC, as there are some claims inferring that it may depend on the designed scenarios of utilizing the residual resources (Schmidt and Brandao, 2013). For instance, if $\mathrm{C}_{5}$ molasses produced in system A and system $\mathrm{C}$ was to be regarded as protein source, and assumed to displace soymeal then there could be a state where other value chains are affected (Bos et al., 2016; Schmidt and Brandao, 2013). This effect, however, can be ignored in the current study, as the consequences were accounted with respect to different reference situation of straw utilization. Other alternative scenarios for assessing 
the consequences of straw could be on their feed values (Tonini et al., 2016). Regardless of any scenarios, most importantly double counting on any cases should be avoided (Finkbeiner, 2013; Pawelzik et al., 2013).

Furthermore, the iLUC factor assumed for ALCA approach is also uncertain along with the changes in the future yield of crops (Finkbeiner, 2013), as the factor was found calculated based on the "global mix" for agricultural exports (Fritsche et al., 2010Fritsche et al., 2010). It is therefore important to reach to a standardized methodology that can be applied for assessing iLUC factors and used for calculating the carbon footprints of biobased products.

\section{Conclusions}

The current study highlights that the benefits of the system integration for bioethanol and biobased lactic acid productions were in terms of higher net savings of GHG emissions, NRE use and EP compared to the standalone systems. However, the obtained ALO was higher in the integrated system than the standalone system. Based on the comparison of the results obtained within CLCA and ALCA approaches, it can be concluded that the recommendations for producing biobased products from an integrated system would be the same, regardless of the approach used. The two approaches had similar impact pattern for most of the impact categories, e.g. as was revealed from the environmental differences obtained from the comparison among the biorefinery systems, and from the hotspots identification. Both bioethanol and biobased lactic acid had net environmental gains compared to petrol and conventional lactic acid respectively, regardless of the approach used.

GHG emissions in agriculture stage were determined by the emission of nitrous oxide and due to SOC change, whereas in biorefinery processes it was determined by emissions related to: energy input and from the enzyme production. SOC change was important to partly mitigate the GHG emissions in an integrated system.

The results also showed that the net avoided impact would vary along with the different assumptions on marginal products. For example, system B and system $\mathrm{C}$ were with lower avoided impacts when locally produced grass-silage was assumed as marginal source of energy-feed instead of Ukrainian barley, as discussed in the sensitivity analysis. The study also showed that the benefits of recirculating intermediate rawmaterials were optimize the performance of biorefinery and to reduce the environmental footprints of biobased products. Example, the recirculation of $\mathrm{C}_{5}$ sugar resulted to increase the yield of bioethanol by $14 \%$, which eventually reduced the GHG emissions approximately by $12-29 \%$ compared to the case of fermenting only the $\mathrm{C}_{6}$ sugar, as discussed in the sensitivity analysis for systems A and C.

Finally, for the optimizations of biorefinery systems following resource integrations can be further beneficial: (i) utilization of intermediate raw materials for producing biochemicals, e.g. in system A, even after the enzymatic hydrolysis, the glucose can be partitioned to produce both fermentable products, bioethanol and biobased lactic acid, (ii) recirculation of enzyme. Likewise, environmental sustainability assessments of the selected biobased products in a commercial scale is inevitably 
1 relevant to attract the investors and for formulating conducive policies. Last but not least, economic

2 evaluation of producing the biobased products is also relevant for systemic sustainability evaluations

3 of biobased products.

4 Acknowledgement

5 The article is written as part of a $\mathrm{PhD}$ study and a subsequent post-doc at the Department of 6 Agroecology, Aarhus University (AU), Denmark. The study is co-funded by the Bio-Value Platform 7 (http://biovalue.dk/), funded under the SPIR initiative by The Danish Council for Strategic Research 8 and The Danish Council for Technology and Innovation, case no: 0603-00522B, and the $9 \quad$ www.dNmark.org Research Alliance. The first author would like to thank to the Graduate School of 10 Science and Technology (GSST) of AU for the $\mathrm{PhD}$ scholarship. Sincere gratitude also goes to J esper 11 Hedal Kløverpris and the team from the Novozymes for providing the information on environmental 12 burden of producing enzyme. The first author is also indebted to Lorie Hamilin from the Institute of 13 Soil Science and Plant Cultivation, Poland, for her constructive suggestions to this study, provided 14 at the time the current study was initially presented.

15 Appendix A: Supplementary data

16 Appendix B: Graphical abstract 


\section{Figure. captions}

2 Fig. 1. Resource flow and system boundary of system A. Electricity produced represents net values

3 of the system (i.e., plant's own consumptions are subtracted). The dotted lines indicate the avoided 4 products considered in the CLCA approach.

5 Fig. 2. Resource flow and system boundary of system B. Electricity produced represents net values 6 of the system (i.e., plant's own consumptions are subtracted). The dotted lines indicate the avoided 7 products considered in the CLCA approach.

8 Fig. 3. Resource flow and system boundary of system C. Electricity produced represents net values 9 of the system (i.e., plants' own consumptions are subtracted). The dotted lines indicate the avoided 10 products considered in the CLCA approach.

11 Fig 4. Contribution of processes involved in the entire biobased products chains. 


\section{List of Tables:}

2 Table 1. Biobased products and assumed substitutable products in the conventional market.

\begin{tabular}{|c|c|}
\hline Biobased products and unit (kg) & $\begin{array}{l}\text { Substitutable products for co-products scenarios and } \\
\text { data sources }\end{array}$ \\
\hline Bioethanol & Petrol \\
\hline Lactic acid (kg) & Conventional Lactic acid: (GLO) marketa, \\
\hline Feed protein & Soybean meal: (GLO) marketa,b \\
\hline Fodder silage & Ukrainian barley (Ukraine), as energy feed c \\
\hline (mainly fiber-residues) (kg) & ((data as: Gross (GLO) barley grain to generic marketa)) \\
\hline Electricity (kWh) & Coal fired electricity production, $\mathrm{DK}^{\mathrm{a}, \mathrm{d}}$. \\
\hline Digestate $(\mathrm{kg})^{\mathrm{e}}$ & Recovered from the designed systems (Figs. 1-3) \\
\hline \multirow[t]{2}{*}{ Added functions } & Conventional lactic acid $(\text { System } \mathrm{A})^{\mathrm{f}}$ \\
\hline & Bioethanol based on biomass (System B)g \\
\hline
\end{tabular}

\section{Assumptions:}

a Database for CLCA and ALCA approach adapted from Ecoinvenet v3 (Weidema et al., 2013).

b Crude Protein (CP) for feed protein =65\% CP (O’Keeffe et al., 2011). Soybean meal with 50\% CP per t DM (FAOSTAT, 2013) was proportionately calculated for the substitutable amount in CLCA approach.

c Ukrainian barley as marginal feed (Muñoz et al., 2014; Schmidt and Brandao, 2013). Feed energy value and the equivalent mass were calculated as 15.2 and 11.9 MJ per kg DM for barley and alfalfa respectively (Møller et al., 2005).

dMarginal electricity = Coal as fuel type (Lund et al., 2010; Mathiesen et al., 2009).

e Substituting marginal synthetic fertilizers: Calcium Ammonium Nitrate (CAN, Triple super phosphate $\left(\mathrm{P}_{2} \mathrm{O}\right.$ ) , Potassium Chloride $\left(\mathrm{K}_{2} \mathrm{O}\right)$ (Hamelin et al., 2012; Hamelin et al., 2011; Tonini et al., 2012).

f Similar process flow as mentioned for avoided product, but consequential and allocation unit process data were used. See footnote ' $a$ '.

f Ethanol (99.7\%) from biomass fermentation (Europe without Switzerland) adapted from Ecoinvent (Weidema et al., 2013). 
1 Table 2. Basic assumptions on the parameters considered in the inventory analysis.

\begin{tabular}{|c|c|c|c|}
\hline \multicolumn{2}{|c|}{ Parameters } & \multirow[t]{2}{*}{ Values } & \multirow[t]{2}{*}{ References } \\
\hline & Lower heating value & & \\
\hline & Bioethanol (MJ / kg) & 28.09 & $\begin{array}{l}\text { (Cherubini and Ulgiati, } \\
\text { 2010) }\end{array}$ \\
\hline & Lignin (MJ / kg) & 22.9 & $\begin{array}{l}\text { (Cherubini and Ulgiati, } \\
\text { 2010) }\end{array}$ \\
\hline & Methane $\left(\mathrm{CH}_{4}\right)\left(\mathrm{MJ} / \mathrm{m}^{3}\right)$ & 35.8 & (Jørgensen, 2009) \\
\hline & $\begin{array}{l}\text { Lactic acid } \\
\text { (assumed similar to orgal }\end{array}$ & 13 & $\begin{array}{l}\text { (European Commission, } \\
1990)\end{array}$ \\
\hline
\end{tabular}

B. Parameters for biogas production:

i. $\mathrm{C}_{5}$ molasses (System A)

(Drosg et al., 2012)

- Total solids (TS) ${ }^{\mathrm{a}}$

$31.1 \%$

- Volatile solids (VS) a

$30.1 \%$

ii. Stillage fractions (System A)

\begin{tabular}{|c|c|c|}
\hline $\begin{array}{l}-\mathrm{TS}^{\mathrm{b}} \\
-\mathrm{VS}^{\mathrm{b}}\end{array}$ & $\begin{array}{l}12 \% \\
10.2 \%\end{array}$ & See footnote \\
\hline $\begin{array}{l}\text { iii. Residues from decanted press } \\
\text { juice (System B) VSc }\end{array}$ & $82 \%$ of $\mathrm{DM}^{\mathrm{c}}$ & \\
\hline $\begin{array}{l}\text { C. } \quad \text { Emission factors } \\
\text { (g per } \mathrm{MJ} \text { bioethanol production) }{ }^{\mathrm{d}}\end{array}$ & $\begin{array}{l}\mathrm{NOx}=38, \mathrm{CH}_{4}=1.5 \\
\mathrm{~N}_{2} \mathrm{O}=0.8\end{array}$ & $\begin{array}{l}\text { (Danish Energy Agency, } \\
\text { 2012) }\end{array}$ \\
\hline \multicolumn{3}{|l|}{ D. Heat and electricity inpute } \\
\hline i. Biogas digester & $\begin{array}{l}\text { Heat }(\mathrm{H})=1110 \quad \mathrm{MJ}_{\mathrm{h}} \\
\text { Electricity }(\mathrm{E})=660 \mathrm{MJ}_{\mathrm{e}}\end{array}$ & $\begin{array}{l}\text { (Berglund and } \\
\text { Börjesson, 2006; } \\
\text { Pugesgaard et al., 2013) }\end{array}$ \\
\hline ii. Combustion of lignin & $\begin{array}{l}\mathrm{H}=40 \mathrm{MJ}_{\mathrm{h}} \text { and } \\
\mathrm{E}=660 \mathrm{MJ} \mathrm{e}\end{array}$ & $\begin{array}{l}\text { Assumed from straw } \\
\text { fired in CHP (Nielsen, } \\
2004 \text { ) }\end{array}$ \\
\hline $\begin{array}{l}\text { E. Nutrient content in the digestate, } \\
\text { in } \mathrm{g} / \mathrm{kg} \text { digestate (System A and } \\
\text { B) }{ }^{\mathrm{f}}(\mathrm{N}, \mathrm{P}, \mathrm{K})\end{array}$ & $5,0.9,2.8$ respectively & $\begin{array}{l}\text { (Drosg et al., 2015; } \\
\text { O’Keeffe et al., 2011) }\end{array}$ \\
\hline $\begin{array}{ll}\text { F. Prices for computing allocation } \\
\text { factors }\end{array}$ & & \\
\hline - $\quad$ Bioethanol (Euro/ MJ )g & 0.03 & \\
\hline - Electricity (Euro / kWh)h & 0.25 & \\
\hline - Heat $(\text { Euro/MJ })^{\mathrm{i}}$ & 0.03 & \\
\hline - $\mathrm{KCl}($ Euro/kg)j & 0.28 & \\
\hline - Lactic acid (Euro/kg)k & 1.36 & \\
\hline
\end{tabular}


- Feed protein (Euro/kg) 10.33

- Fodder silage $(\mathrm{EUR} / \mathrm{kg})^{\mathrm{m}} \quad 0.02$

\section{Assumptions:}

a TS and VS of the $\mathrm{C}_{5}$ molasses are based on the total weight of molasses.

bTS and VS of the stillage fractions are based on the total weight of stillage.

c DM represents the substrate available for biogas after the decanted press juice (O'Keeffe et al., 2011) (SI-6, Fig. S-6.1)

d Assumed similar to coal.

e Energy input per t DM fuel.

${ }^{f}$ NPK content (digestate) are per t fresh substrates (Fig. 1 and Fig. 2).

gAverage price of denaturated fuel ethanol for the period May 2006-Apr 2016 (index mundi, 2016; PURE) and validated with EUBIA (2016).

h Price of electricity applied representative for the average Danish electricity price, including VAT and other recoverable taxes and levies the period of 2011-2015 (European Commission, 2012).

i Based on annual heat price of Denmark (Energitilsynet, 2012).

j Average price of $\mathrm{KCl}$, calculated for K using K to KCL molar ratio (May 2006-Apr 2016) (index mundi, 2016).

k Price taken after Refs. (Lynd et al., 2005; Wee et al., 2006). Lactic acid considered a purity level of $90 \%$ (Kamm et al., 2009).

${ }^{1}$ Price of protein based on soybean meal (May 2006-Apr 2016) (index mundi, 2016; Statistics Denmark, 2016). Danish database represents feed compound for cattle (except calves, with high protein content). Price proportionately calculated for the crude protein content of soymeal (50\% of the DM) (Dalgaard et al., 2007) and protein extracted from the GBR (65\% CP of the DM of the protein cake) (O’Keeffe et al., 2011).

m Silage fodder traded in Denmark from 2005-2011 (Statistics Denmark, 2016). 
1 Table 3. Primary input and output of materials related to the conversion of 1 t straw (with $85 \%$ DM)

2 to bioethanol (System A), all data are per $1 \mathrm{t}$ straw.

\begin{tabular}{|c|c|c|}
\hline Materials & Units & Amount \\
\hline \multicolumn{3}{|l|}{ A. Input } \\
\hline Straw & $\mathrm{t}(85 \% \mathrm{DM})$ & 1 \\
\hline Water ${ }^{\mathrm{a}}$ & $\mathrm{kg}$ & 2747 \\
\hline Enzyme $^{a}$ & $\mathrm{~kg}$ & 40 \\
\hline \multicolumn{3}{|l|}{ Energyb } \\
\hline - Heat & $\mathrm{MJ}_{\mathrm{h}}$ & 4071 \\
\hline - Electricity (kWh elec/t straw) & $\mathrm{MJ}_{\mathrm{e}}$ & 850 \\
\hline Additives & $\mathrm{kg}$ & \\
\hline - Diaamonium Phosphate (DAP)c $^{c}$ & & 1.87 \\
\hline - Corn steep liquor ${ }^{c}$ & & 14.2 \\
\hline$-\mathrm{NaOH}(49 \%)^{\mathrm{b}}$ & & 0.53 \\
\hline - Ammonia water (25\%) $)^{b}$ & & 1.76 \\
\hline \multicolumn{3}{|l|}{ B. Output (Primary) } \\
\hline - Bioethanola $^{\mathrm{a}}$ & $\mathrm{kg}$ & 186 \\
\hline - $\mathrm{C}_{5}$ molasses + residues from stillaged & $\mathrm{kg}$ & 392 \\
\hline - Lignin ${ }^{\mathrm{d}}$ & $\mathrm{kg}$ & 152 \\
\hline$-\mathrm{KCl}^{\mathrm{e}}$ & & 12 \\
\hline \multicolumn{3}{|l|}{ Emissions $^{\mathrm{d}}$} \\
\hline \multicolumn{3}{|l|}{ - During biomass production } \\
\hline \multirow[t]{2}{*}{ o $\quad \mathrm{N}_{2} \mathrm{O}-\mathrm{N}$ (total) } & \multirow[t]{2}{*}{$\mathrm{kg} \mathrm{CO} 2 \mathrm{eq}$} & $-15^{f}$ \\
\hline & & 679 \\
\hline \multirow[t]{2}{*}{ o due to SOC change } & \multirow[t]{2}{*}{$\mathrm{kgCO}_{2} \mathrm{eq}$} & $143^{\mathrm{f}}$ \\
\hline & & $-59 g$ \\
\hline o $\quad$ N-leaching $\left(\mathrm{NO}_{3}-\mathrm{N}\right)$ & $\mathrm{kgN}$ & $1.4^{\mathrm{g}}$ \\
\hline o Plosses & $\mathrm{kgP}$ & $0.06 \mathrm{~g}$ \\
\hline \multicolumn{3}{|l|}{ - During biomass conversion } \\
\hline $\mathrm{o} \quad \mathrm{CO}_{2}$ & $\mathrm{kgCO}_{2} \mathrm{eq}$ & 162 \\
\hline o Ethanol & $\mathrm{kg}$ & 12 \\
\hline
\end{tabular}

\footnotetext{
Assumptions:

aAverage of the studies from Bentsen et al. (2006), Kaparaju et al. (2009) and Wang et al. (2013).

b Based on Bentsen et al. (2006).

${ }^{c}$ Based on Wang et al. (2013).

d Based on Bentsen et al. (2006) and Kaparaju et al. (2009).
} 
e Total mass from the hydrolysate and stillage fractions. Recovery rate 90\% (Larsen et al., 2008).

f Emissions are related to consequences of straw removal (Parajuli et al., 2016). Negative value indicates mitigation potential. Total $\mathrm{N}_{2} \mathrm{O}-\mathrm{N}$ emission (direct + indirect) $=-0.033 \mathrm{~kg} \mathrm{~N} \mathrm{~N}_{2} \mathrm{O}-\mathrm{N} \mathrm{t} \mathrm{DM}$ 1.

g Emissions represented for ALCA approach. Emissions calculated for winter wheat were economically allocated to straw, i.e. 19\% of winter wheat (Parajuli et al., 2016). Negative value indicates soil $\mathrm{C}$ sequestration. Other related emissions per t DM: $\mathrm{N}_{2} \mathrm{O}-\mathrm{N}$ emission (direct + indirect) $=0.22 \mathrm{~kg} \mathrm{~N} 2 \mathrm{O}-\mathrm{N}$; $\mathrm{NH}_{3}$-emission $=0.031 \mathrm{~kg} \mathrm{NH}-\mathrm{N}$; $\mathrm{NOx}-\mathrm{N}=0.1107 \mathrm{~kg}$ (Parajuli et al., 2016). Detailed on the other material inputs are shown in SI-1, Table S-1.1. 
1 Table 4. Input-output of materials for the conversion of 1t DM alfalfa to biobased lactic acid (system 2 B), all data are per t DM of alfalfa.

\begin{tabular}{|c|c|c|}
\hline Materials & Unit & Amount Remarks \\
\hline \multicolumn{3}{|l|}{ Input } \\
\hline Alfalfa & tDM & 1 \\
\hline \multicolumn{3}{|l|}{ Energy } \\
\hline - Heat, steama & $\mathrm{MJ}_{\mathrm{h}}$ & 126 \\
\hline - Electricitya & $\mathrm{MJ}_{\mathrm{e}}$ & 211 \\
\hline Fermentation mediab & $\mathrm{kg}$ & 5.94 \\
\hline Enzyme & $\mathrm{kg}$ & 18 \\
\hline Waterc & $\mathrm{kg}$ & 450 \\
\hline
\end{tabular}

\section{Output $^{\mathrm{d}}$}

\begin{tabular}{|c|c|c|c|}
\hline Lactic acid & $\mathrm{kg} \mathrm{DM}$ & 89 & 99 kg (DM 90\%) \\
\hline Feed protein & $\mathrm{kg} \mathrm{DM}$ & 26 & $\begin{array}{l}\text { DM } 40 \% \text {, fodder protein the pure form of } \\
\text { CP (65\%). }\end{array}$ \\
\hline Fodder silage & $\mathrm{kg} \mathrm{DM}$ & 261 & 652 kg (DM 40\%) \\
\hline VS, residues for biogas & $\mathrm{kg} \mathrm{DM}$ & 152 & Fresh weight 2.95 t (6\% DM) \\
\hline
\end{tabular}
- During biomass production

- Due to SOC change $\quad \mathrm{kg} \mathrm{CO}_{2}$ eq $\quad$ - 37e $\quad$ (Parajuli et al., 2016)

\begin{tabular}{|c|c|c|c|}
\hline$-\mathrm{N}_{2} \mathrm{O}-\mathrm{N}$ & $\mathrm{kg} \mathrm{CO}_{2} \mathrm{eq}$ & 13 & (Parajuli et al., 2016) \\
\hline - $\quad$ N-leaching $\left(\mathrm{NO}_{3}-\mathrm{N}\right)$ & $\mathrm{kgN}$ & 3.4 & (Parajuli et al., 2016) \\
\hline - $\mathrm{P}$ losses & $\mathrm{kgP}$ & 0.13 & (Parajuli et al., 2016) \\
\hline
\end{tabular}

\footnotetext{
Assumptions:

a Calculated based on O'Keeffe et al. (2011) and Kamm et al. (2009).

b Calculated based on Kamm et al. (2010) (see section 2.5.1).

c Calculated also considering the re-circulated water (O’Keeffe et al., 2011).

d Products output calculated based on O'Keeffe et al. (2011) and Kamm et al. (2009) for $1 \mathrm{t}$ DM of alfalfa (with 35\% DM at harvest). Feed protein, estimated equivalent to soymeal (based on CP content) ( Table 2). = $34 \mathrm{~kg} \mathrm{DM}$.

e Calculated from Parajuli et al. (2016); negative value indicates soil C sequestration. Emissions per t DM : $\mathrm{N}_{2} \mathrm{O}-\mathrm{N}=0.03 \mathrm{~kg} ; \mathrm{NH}_{3}-\mathrm{N}=0.04 \mathrm{~kg} ; \mathrm{NOx}-\mathrm{N}=0.01 \mathrm{~kg}$ (Parajuli et al., 2016).
} 
1 Table 5: Energy balance calculated for the biorefinery plants. The balance accounted all useful 2 energy consumption within the biorefinery systems.

\begin{tabular}{|c|c|c|}
\hline & Units & Amount \\
\hline A. $\quad$ System $A$ & & \\
\hline \multicolumn{3}{|c|}{ Total energy input (per 1t, 85\% DM straw) } \\
\hline - Heat & $\mathrm{GJ}_{\mathrm{h}}$ & 4.1 \\
\hline - Electricity & $\mathrm{Gj}_{\mathrm{e}}$ & 0.8 \\
\hline \multicolumn{3}{|c|}{ Total energy output } \\
\hline - Heat & $\mathrm{GJ}_{\mathrm{h}}$ & 2.1 \\
\hline - Electricity & $\mathrm{Gj}_{\mathrm{e}}$ & 1.7 \\
\hline \multicolumn{3}{|l|}{ Deficit/surplus } \\
\hline - Heat & $\mathrm{GJ}_{\mathrm{h}}$ & -2.01 \\
\hline - Electricity & $\mathrm{Gj}_{\mathrm{e}}$ & 0.83 \\
\hline \multicolumn{3}{|c|}{ B. $\quad$ System B } \\
\hline \multicolumn{3}{|c|}{ Total Energy input (per 1 t DM, alfalfa) } \\
\hline - Heat & $\mathrm{GJ}_{\mathrm{h}}$ & 0.86 \\
\hline - Electricity & $\mathrm{Gj}_{\mathrm{e}}$ & 0.31 \\
\hline \multicolumn{3}{|c|}{ Total energy output } \\
\hline - Heat & $\mathrm{GJ}_{\mathrm{h}}$ & 0.59 \\
\hline - Electricity & $\mathrm{Gj}_{\mathrm{e}}$ & 0.84 \\
\hline \multicolumn{3}{|l|}{ Deficit/surplus } \\
\hline - Heat & $\mathrm{GJ}_{\mathrm{h}}$ & -0.99 \\
\hline - Electricity & $\mathrm{Gj}_{\mathrm{e}}$ & 0.53 \\
\hline \multicolumn{3}{|c|}{ C. $\quad$ Net balance (System C) } \\
\hline - Heat & $\mathrm{GJ}_{\mathrm{h}}$ & -2.78 \\
\hline - Electricity & $\mathrm{Gj}_{\mathrm{e}}$ & 1.3 \\
\hline
\end{tabular}

4 
1 Table 6. Environmental impact potentials of producing bioethanol and lactic acid from standalone plants and from system C ( FU is “ $1 \mathrm{MJ} \mathrm{EtOH}+1 \mathrm{~kg}_{\mathrm{LA}}$ ”).

2 Negative values indicate the environmental impact abatement potentials.

\begin{tabular}{|c|c|c|c|c|c|c|c|}
\hline \multirow[t]{3}{*}{ Impact categories } & \multirow[t]{3}{*}{ Units } & \multicolumn{3}{|c|}{ CLCA } & \multicolumn{3}{|c|}{ ALCA } \\
\hline & & System & System & System & System & System & C-ntom $\mathrm{C}$ \\
\hline & & $\mathrm{A}$ & B & $\mathrm{C}$ & A & B & system \\
\hline $\mathrm{GWP}_{100}$ & $\mathrm{~kg} \mathrm{CO}_{2} \mathrm{eq}$ & & & & & & \\
\hline - without iLUC & & $0.13(0.16)^{\mathrm{a}}$ & $0.39(1.81)^{\mathrm{a}}$ & $0.05(0.15)^{\mathrm{a}}$ & 3.78 & 4.4 & 3.02 \\
\hline - $\quad$ with iLUC & & - & 0.64 & 0.29 & 3.85 & 4.7 & 3.43 \\
\hline & & $1.5^{*} 10^{-4}$ & $-1.4 * 10^{-3}$ & $1.3^{*} 10^{-5}$ & & & \\
\hline $\mathrm{EP}$ & $\mathrm{kg} \mathrm{PO}_{4} \mathrm{eq}$ & $\left(1.8^{*} 10^{-4}\right)^{\mathrm{a}}$ & $\left(3.7 * 10^{-3}\right)^{\mathrm{a}}$ & $\left(2.9^{*} 10^{-4}\right)^{\mathrm{a}}$ & $4.9 * 10^{-3}$ & $1.4 * 10^{-2}$ & $5 * 10^{-3}$ \\
\hline NRE use & MJ eq & $1.25(1.51)^{\mathrm{a}}$ & $14.63(29.22)^{a}$ & $0.38(1.39)^{\mathrm{a}}$ & 45 & 65 & 31 \\
\hline ALO & $\mathrm{m}^{2} \mathrm{a}$ & $0.02(0.02)^{a}$ & $1.99(3.33)^{\mathrm{a}}$ & $0.11(0.17)^{\mathrm{a}}$ & 2.68 & 8.6 & 5.31 \\
\hline
\end{tabular}

a Values in the parenthesis are the gross impacts, i.e. without avoided impacts. 
1 Table 7. Contribution patterns of the co-products for avoiding and sharing the environmental 2 impacts within CLCA and ALCA approach. Units per FU in each system are: net $\mathrm{GWP}_{100}=\mathrm{kg} \mathrm{CO}_{2} \mathrm{eq}$,

$3 \quad \mathrm{EP}=\mathrm{kg} \mathrm{PO}_{4} \mathrm{eq}$, $\mathrm{NRE}$ use $=\mathrm{MJ}$ eq , and $\mathrm{ALO}=\mathrm{m}^{2}$.

\begin{tabular}{|c|c|c|c|c|c|c|c|c|}
\hline & \multicolumn{4}{|c|}{ CLCA } & \multicolumn{4}{|c|}{ ALCA } \\
\hline Contributions & Electricity & $\begin{array}{c}\text { Recovered } \\
\text { nutrients }\end{array}$ & $\begin{array}{c}\text { Feed } \\
\text { protein }\end{array}$ & $\begin{array}{c}\text { Fodder } \\
\text { silage }\end{array}$ & Electricity & $\begin{array}{l}\text { Recovered } \\
\text { nutrients }\end{array}$ & $\begin{array}{c}\text { Feed } \\
\text { protein }\end{array}$ & $\begin{array}{c}\text { Fodder } \\
\text { silage }\end{array}$ \\
\hline \multicolumn{9}{|l|}{ System A } \\
\hline $\mathrm{GWP}_{100}$ & -0.03 & -0.001 & - & - & 0.68 & 0.81 & - & - \\
\hline $\mathrm{EP}$ & $-3 * 10^{-5}$ & $-9 * 10^{-7}$ & - & - & $9 * 10^{-4}$ & $1 * 10^{-3}$ & - & - \\
\hline NRE use & -0.25 & -0.02 & - & - & 8.18 & 9.69 & - & - \\
\hline ALO & $-2 * 10^{-5}$ & $-5 * 10^{-8}$ & - & - & 0.48 & 0.57 & - & - \\
\hline \multicolumn{9}{|c|}{ System B } \\
\hline $\mathrm{GWP}_{100}$ & -0.58 & -0.05 & -0.12 & -0.67 & 0.54 & 0.03 & 0.58 & 0.05 \\
\hline $\mathrm{EP}$ & $-8 * 10^{-4}$ & $-6 * 10^{-5}$ & $-9 * 10^{-4}$ & $-3 * 10^{-3}$ & $2 * 10^{-3}$ & $9 * 10^{-5}$ & $2 * 10^{-3}$ & $2 * 10^{-4}$ \\
\hline NRE use & -5.54 & -0.33 & -0.73 & -8 & 7.95 & 0.46 & 8.64 & 0.72 \\
\hline ALO & $-5^{*} 10^{-4}$ & $-2 * 10^{-5}$ & -0.54 & -0.79 & 1.01 & 0.07 & 1.25 & 0.08 \\
\hline \multicolumn{9}{|c|}{ System C } \\
\hline $\mathrm{GWP}_{100}$ & -0.06 & -0.013 & -0.01 & -0.03 & 0.55 & 0.66 & 0.71 & 0.04 \\
\hline $\mathrm{EP}$ & $-7 * 10^{-5}$ & $-2 * 10^{-5}$ & $-4 * 10^{-5}$ & $-1 * 10^{-4}$ & $9 * 10^{-4}$ & $1 * 10^{-3}$ & $1 * 10^{-3}$ & $7 * 10^{-5}$ \\
\hline NRE use & -0.54 & -0.1 & -0.03 & -0.34 & 5.66 & 6.79 & 7.25 & 0.45 \\
\hline ALO & $-5 * 10^{-5}$ & $-5^{*} 10^{-5}$ & -0.02 & -0.04 & 0.96 & 1.17 & 1.25 & 0.08 \\
\hline
\end{tabular}


1 Table 8. Results obtained from the sensitivity analysis. Units per FU of each system are: net GWP 100

$2=\mathrm{kg} \mathrm{CO} 2$ eq and $\mathrm{NRE}$ use $=\mathrm{MJ}$ eq.

\begin{tabular}{|c|c|c|c|c|c|c|}
\hline & \multirow{3}{*}{$\begin{array}{c}\text { Basic } \\
\text { Scenario }\end{array}$} & \multicolumn{2}{|c|}{ Marginal products } & \multicolumn{3}{|c|}{ Variations in the yield } \\
\hline & & Electricity & Fodder & $+14 \%$ & $+10 \%$ & $-10 \%$ \\
\hline & & a & silage $^{b}$ & $\mathrm{EtOH}$ & LA & LA \\
\hline \multicolumn{7}{|c|}{ System A (per FU) } \\
\hline Net GWP G00 $_{10}$ & 0.13 & 0.14 & - & 0.11 & 0.12 & 0.14 \\
\hline Net NRE use & 1.25 & 1.24 & - & 1.09 & 1.15 & 1.36 \\
\hline \multicolumn{7}{|c|}{ System B (per FU) } \\
\hline Net GWP ${ }_{100}$ & 0.39 & 0.67 & 0.63 & 0.34 & 0.35 & 0.43 \\
\hline Net NRE use & 14.63 & 14.43 & 17 & 12.8 & 13.3 & 16.3 \\
\hline \multicolumn{7}{|c|}{ System C (per FU) } \\
\hline Net GWP100 & 0.05 & 0.08 & 0.06 & 0.05 & 0.04 & 0.05 \\
\hline Net NRE use & 0.38 & 0.4 & 0.55 & 0.29 & 0.33 & 0.4 \\
\hline
\end{tabular}

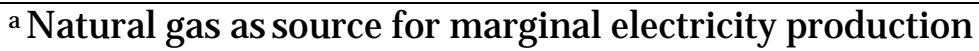

${ }^{\mathrm{b}}$ Grass-silage as a source of energy-feed. 


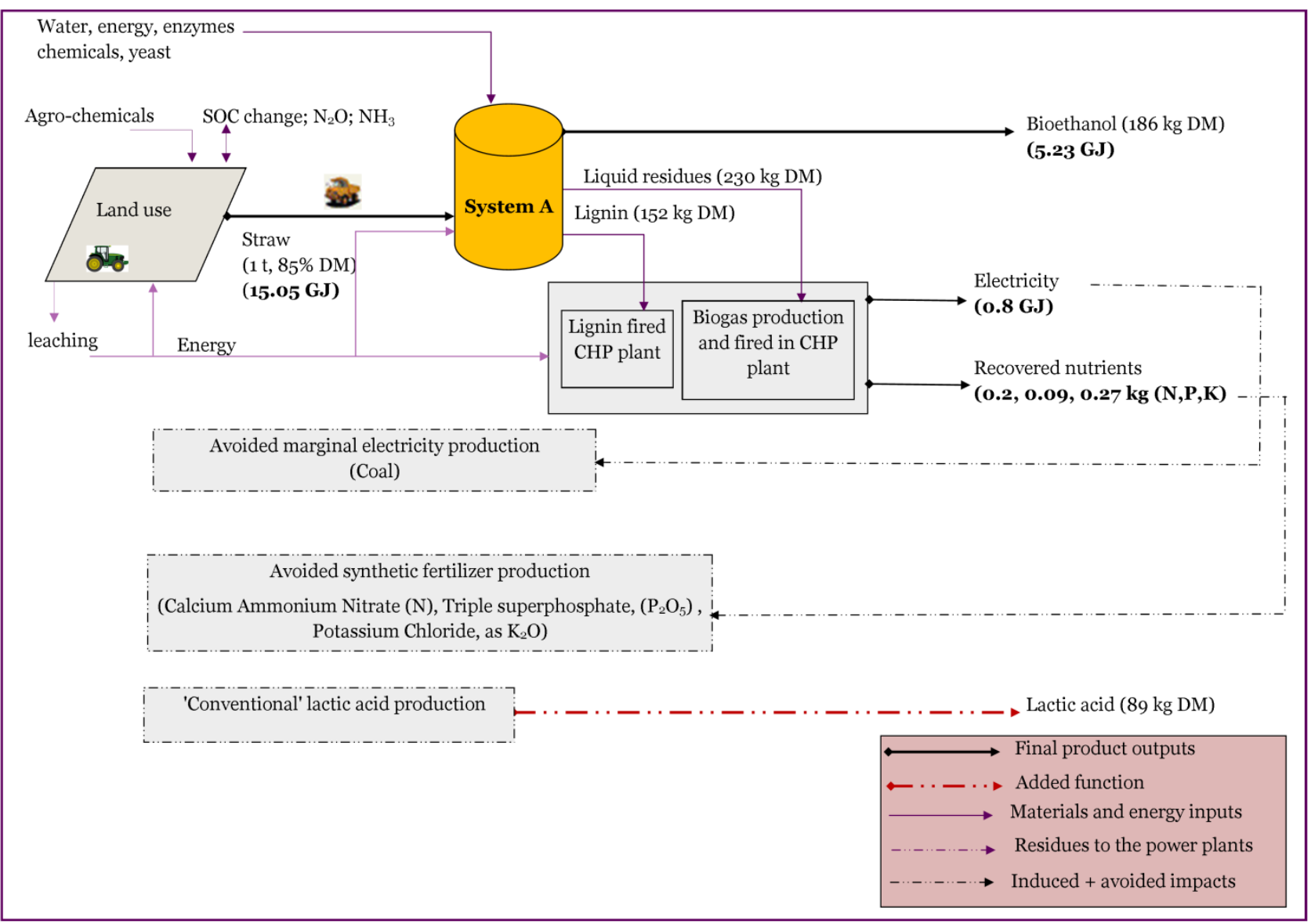

2 Fig. 1. 


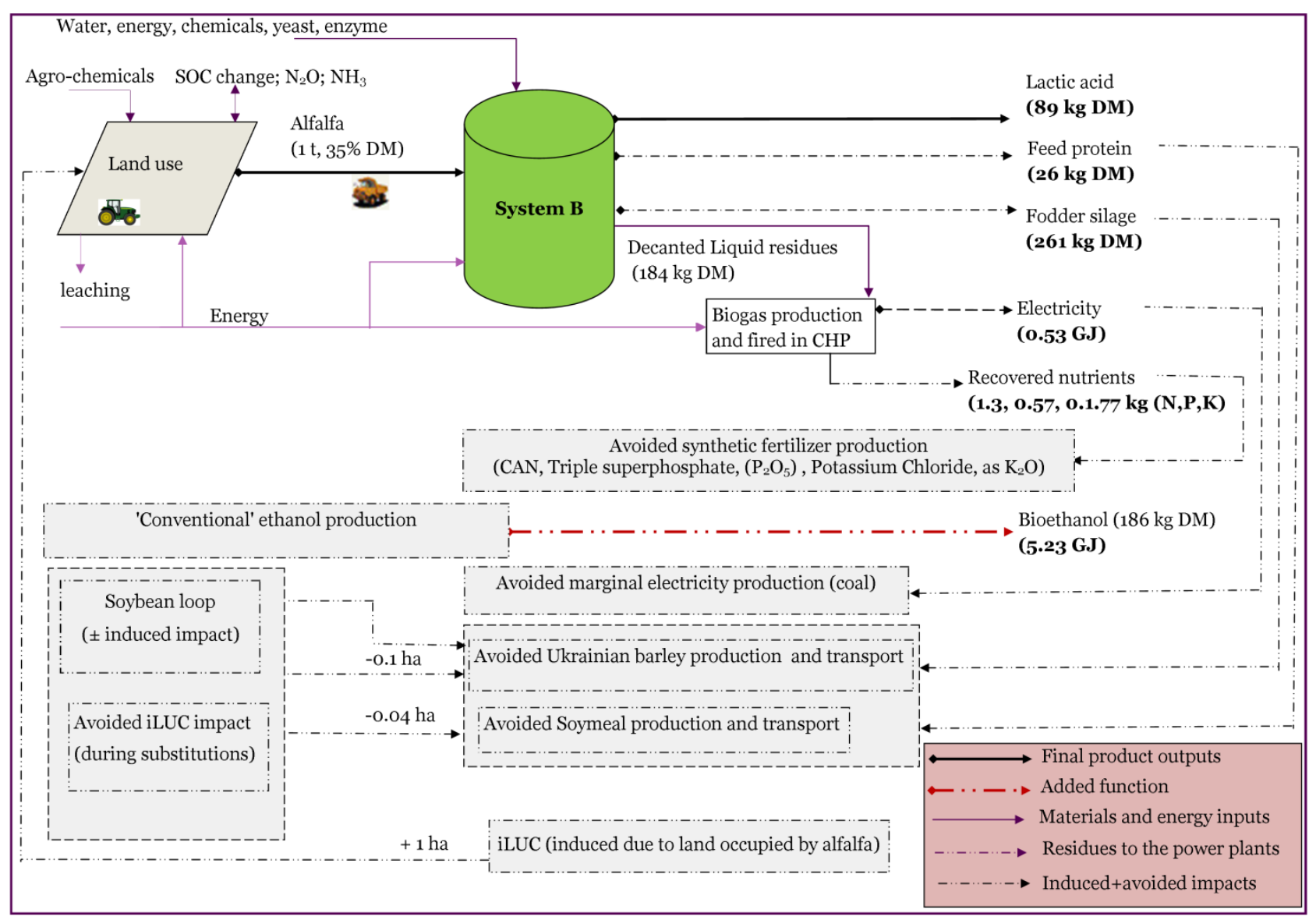

Fig. 2. 


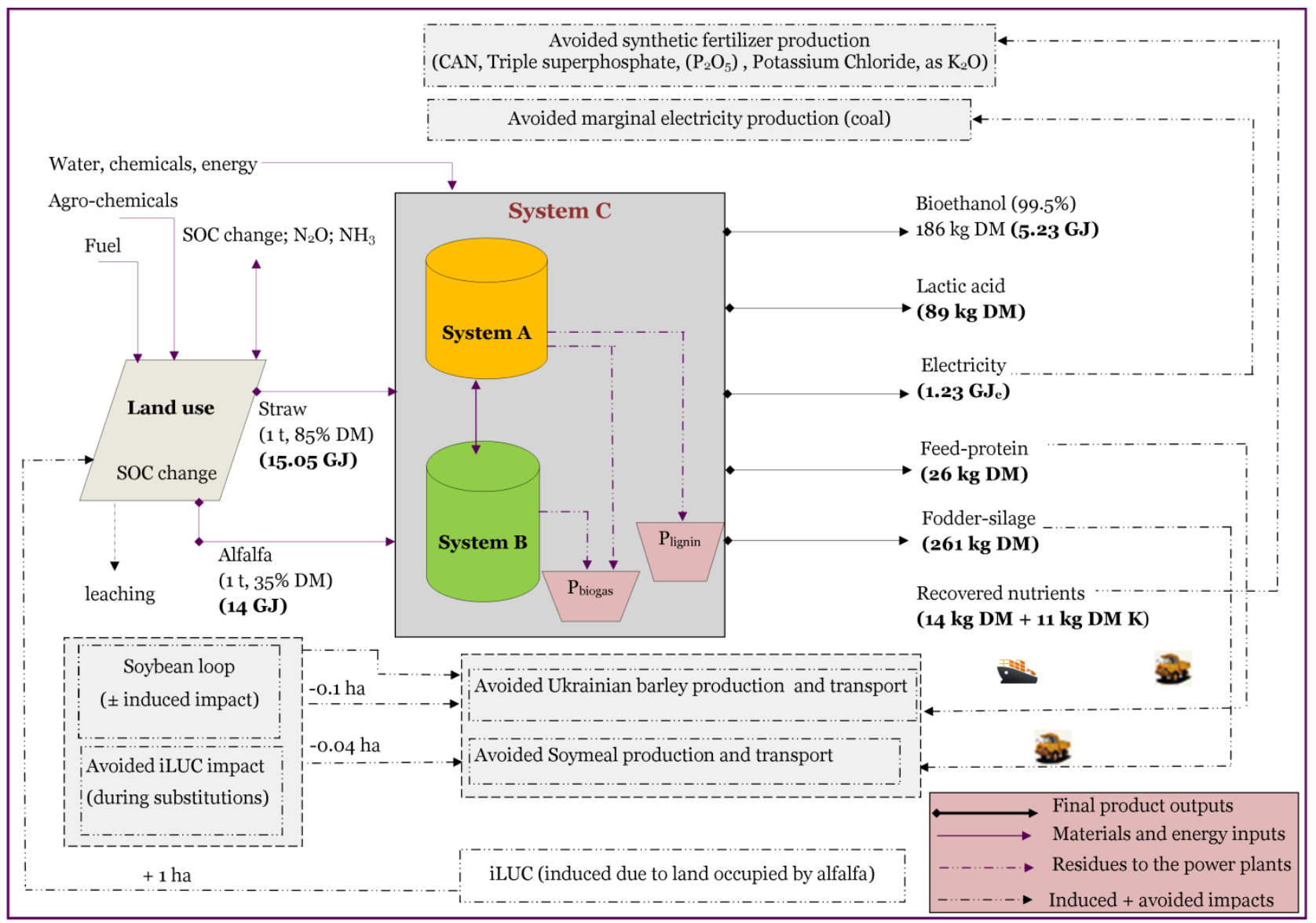

Fig. 3. 
a. System A (CLCA)

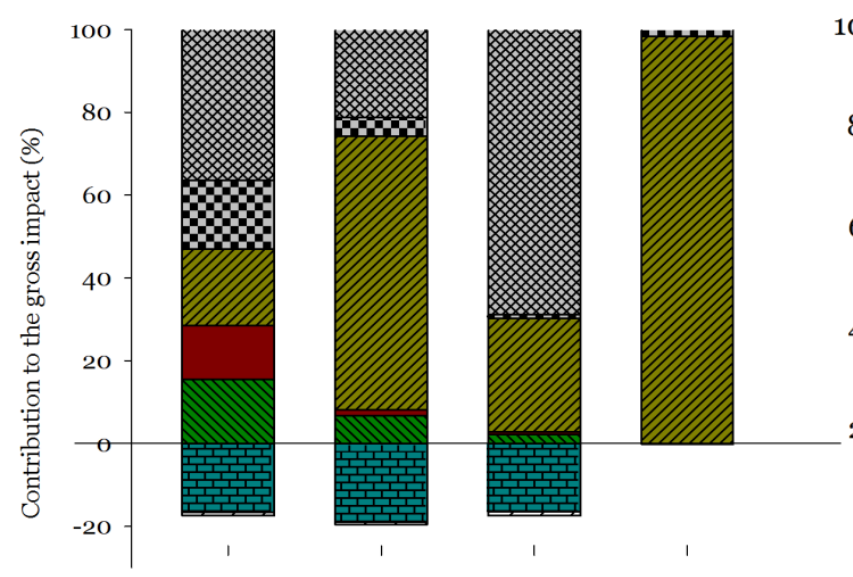

c. System B (CLCA)
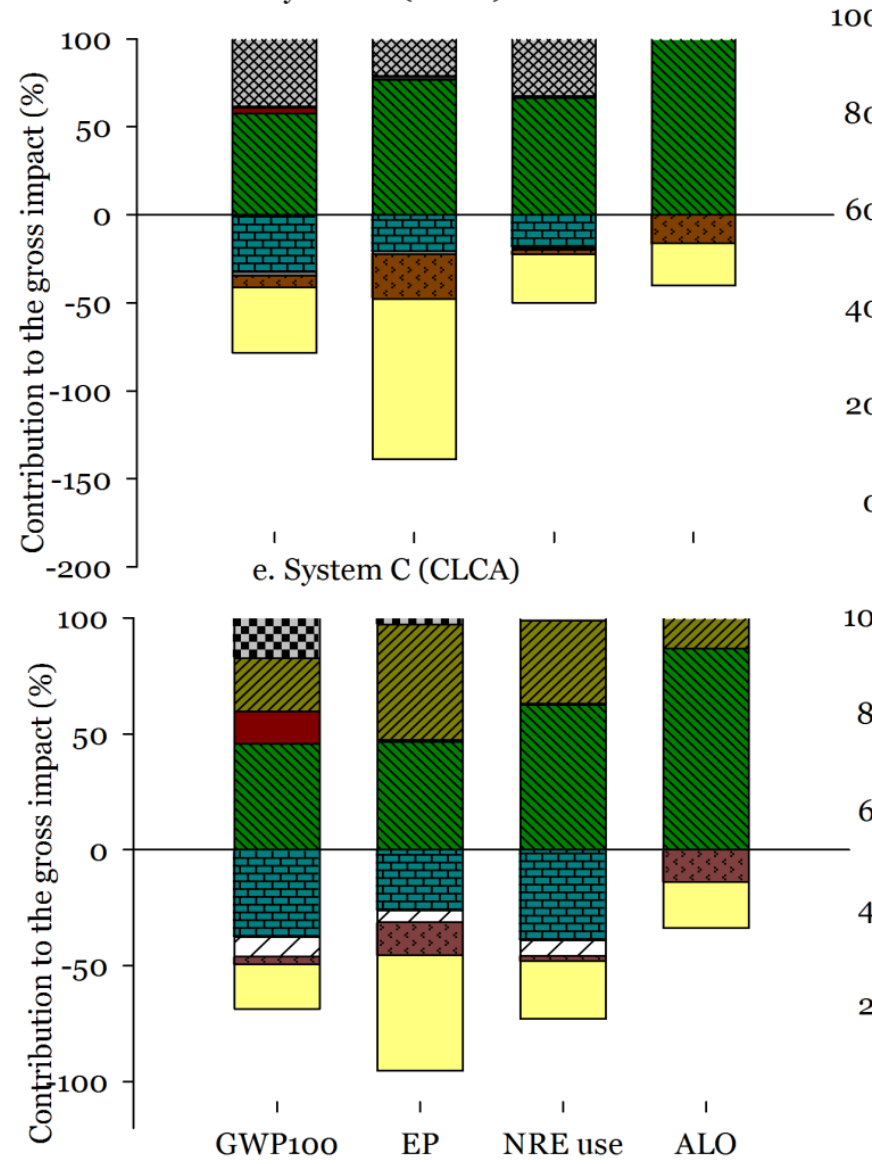

Potential environmental impacts

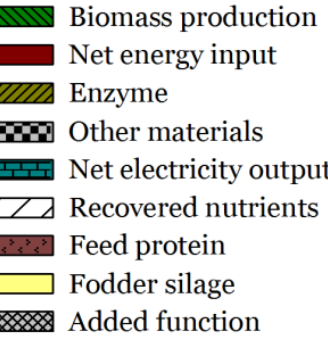

Fig. 4. b. System A (ALCA)

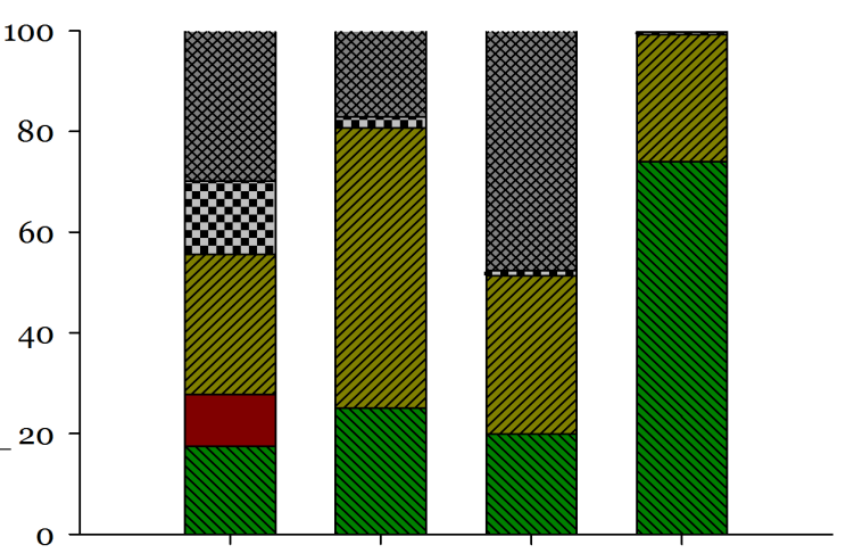

d. System B (ALCA)

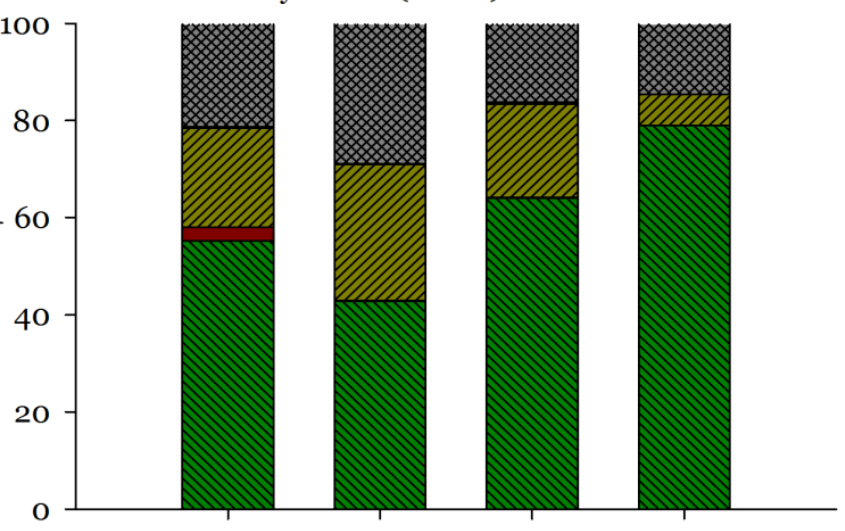

f. System C (ALCA)

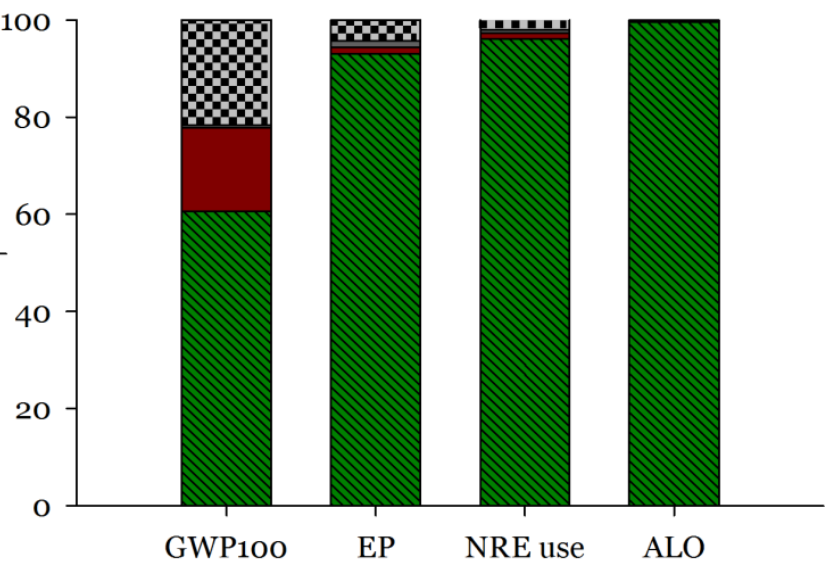

Potential environmental impacts

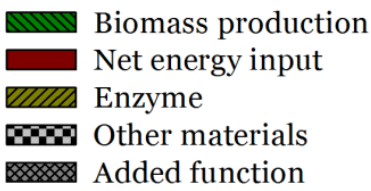




\section{Appendix A: Supplementary data (SI):}

2 Environmental impacts of producing bioethanol and biobased lactic acid from standalone 3 and integrated biorefineries using a consequential and an attributional life cycle assessment 4 approach

5 Ranjan Parajulia,*, Marie Trydeman Knudsena, Morten Birkved ${ }^{\mathrm{b}}$, Sylvestre Njakou Djomo ${ }^{\mathrm{a}}$ 6 Andrea Corona ${ }^{\mathrm{b}}$, Tommy Dalgaarda

7 aDepartment of Agroecology, Aarhus University, Blichers Allé 20, DK-8830 Tjele, Denmark

8 bDepartment of Management Engineering, Technical University of Denmark, Building 424,

9 DK-2800 Lyngby, Denmark

$10 \quad{ }^{*}$ Corresponding author, email: ranjan.parajuli@agro.au.dk, Phone: +4571606831

11 Contents

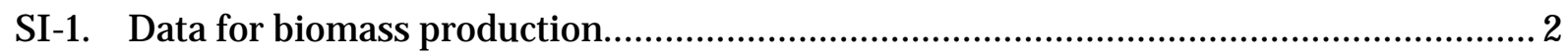

13 SI-2. Parameters and calculation details on the methane yield from the residues 3

SI-3. Supporting parameters and energetic inputs considered in the basic scenario ..... 
SI-1. Data for biomass production

2 Table S-1. Input-output of the materials flow assumed for the alfalfa production, per $1 \mathrm{t}$

3 DM, summarised after Parajuli et al. (2017).

\begin{tabular}{|c|c|c|c|c|}
\hline & Units & Alfalfa & Comments/ Remarks & \\
\hline \multirow[t]{2}{*}{ Biomass output } & t DM/ ha & 12.02 & (Møller & 2005; \\
\hline & & & NaturErhvervstyrelsen, 2015) & \\
\hline
\end{tabular}

\section{Farm inputs}

\begin{tabular}{|c|c|c|c|}
\hline Synthetic fertilizera & $\mathrm{kg} / \mathrm{t} \mathrm{DM}$ & & SEGES (2010) \\
\hline $\mathrm{N}$ & & - & \\
\hline $\mathrm{P}$ & & 3 & \\
\hline K & & 18 & \\
\hline Lime & $\mathrm{kg} / \mathrm{tDM}$ & 4.57 & Based on Hamelin et al. (2012) \\
\hline Pesticides & $\mathrm{kg} / \mathrm{tDM}$ & 0.02 & Based on SEGES (2010) \\
\hline $\begin{array}{l}\text { Direct primary energy } \\
\text { input }\end{array}$ & $\mathrm{MJ} / \mathrm{tDM}$ & 343 & Field preparation and harvesting \\
\hline Transport materials & $\mathrm{t} \mathrm{km} / \mathrm{tDM}$ & 6 & (seed +agri-chemicals) \\
\hline Emissions & & & (Parajuli et al., 2017) \\
\hline $\mathrm{N}_{2} \mathrm{O}$ & $\mathrm{kg} \mathrm{CO} 2 \mathrm{eq} / \mathrm{t} \mathrm{DM}$ & 16 & \\
\hline SOC change & $\mathrm{kg} \mathrm{CO} 2 \mathrm{eq} / \mathrm{t} \mathrm{DM}$ & -37 & \\
\hline Leaching & $\mathrm{kgN} / \mathrm{tDM}$ & 3.4 & \\
\hline Plosses & $\mathrm{kgP} / \mathrm{tDM}$ & 0.14 & \\
\hline Transport biomass & $\mathrm{t} \mathrm{km} / \mathrm{t} \mathrm{DM}$ & 200 & field to the biorefinery plant \\
\hline
\end{tabular}


1 SI-2. Parameters and calculation details on the methane yield from the residues

System A: The volatile solids (VS) (\%) in the stillage fractions of the total wet weight of the stillage was based on Kaparaju et al. (2009) (Table 2). In the case of molasses, of the total wet-weight of the cake the total solids (TS) and VS were assumed, as reported in Drosg et al. (2012) (Table 2). The total nitrogen content in the stillage was assumed as $1.78 \mathrm{~g}$ per $\mathrm{kg}_{\mathrm{EtOH}}$ (Kaparaju et al., 2009), hence ammonia inhibition would be $0.2 \mathrm{~g}$ per $\mathrm{kg}_{\mathrm{EtOH}}$. It is also accelerated with higher temperature. Thus it is wise to avoid thermophilic process temperatures when treating nitrous feedstock such as stillage, hence mesophilic reactors was considered and the conversion efficiency was set lower as explained below.

System B: The total mass of fermentable substrate for the production of methane $\left(\mathrm{CH}_{4}\right)$ was based on the VS (\%) in the decanted press juice (O’Keeffe et al., 2011) (see Table S-1.1).

System C: The substrate available for biogas conversion in System C is the combination of residual resources available from System A and System B (Fig. S-5.1 and Fig. S-6.1).

The total potential methane yield was calculated by utilizing Eq. (i) (Pugesgaard et al., 2013).

$$
\mathrm{CH}_{4}(\text { potential })=\varepsilon * V S * B_{0} * 0.67 \quad \ldots \ldots \text {....Eq. (i) }
$$

where, $\mathrm{CH}_{4}$ (potential) = methane production (kg); VS (in $\mathrm{kg}$, see Table 2); $\mathrm{B}_{\mathrm{o}}$ is the maximum methane-producing capacity of the added material $\left(\mathrm{m}^{3} \mathrm{kgVS}^{-1}\right)$ (see Table S-1.1); $\varepsilon$ $=$ process efficiency $=0.8$, based on the average efficiency of hydrolysate and stillage fractions, as reported in Kaparaju et al. (2009) and 0.67 was the conversion factor from volume to $\mathrm{kg} \mathrm{CH}_{4}$ (Olesen et al., 2004). The energy input to biogas plant was based on Berglund and Börjesson (2006). Methane loss during combustion was set to $1.8 \%$ of the total conversion (Pugesgaard et al., 2013). Conversion of biogas to heat and electricity was 18.69 $\mathrm{MJ}_{\mathrm{h}}$ and 26.7 MJ e respectively per $\mathrm{kg}$ of $\mathrm{CH}_{4}$, with $\mathrm{LHV}$ of $\mathrm{CH}_{4}$ set as $35.8 \mathrm{MJ} \mathrm{m}^{-3}$, and the heat and electricity conversion efficiency were set to 35\% and 50\% (Jørgensen, 2009). Likewise, the amount of substrate available from the GBR to the biogas digester was calculated based on the studies of O'Keeffe et al. (2011), Kamm et al. (2009) and (Kamm et al., 2010) (Fig. S-6.1). In this case, the $B_{0}$ of the added material was assumed 39.5\%, estimated based on Pugesgaard et al. (2013) for crop residues 
1 SI-3. Supporting parameters and energetic inputs considered in the basic scenario

2 Table S-3.1: Energy inputs during the processing of biomass in System B; calculated based 3 on O'Keeffe et al. (2011) and Kamm et al. (2009).

\begin{tabular}{llc}
\hline $\begin{array}{l}\text { Biomass Processing and } \\
\text { stages in GBR }\end{array}$ & Units & per t DM alfalfa \\
\hline Pumping & $\mathrm{kWh} / \mathrm{t}$ & 0.69 \\
\hline $\begin{array}{l}\text { Fiber processing to silage } \\
\text { fodder }\end{array}$ & & \\
\hline \multicolumn{1}{c}{ Pressing } & $\mathrm{kWh} / \mathrm{t}$ & 4.9 \\
\hline Protein extraction & & \\
\hline Steam coagulation & $\mathrm{MJ} / \mathrm{t}$ & 126 \\
Skimming & $\mathrm{kWh} / \mathrm{t}$ & 1.31 \\
Centrifuging & $\mathrm{kWh} / \mathrm{t}$ & 3.41 \\
Decanting & $\mathrm{kWh} / \mathrm{t}$ & 1.03 \\
\hline Lactic acid production & & \\
\hline Stirring & $\mathrm{kWh} / \mathrm{t}$ & 3.75 \\
Ultrafiltration & $\mathrm{kWh} / \mathrm{t}$ & 4.85 \\
Bipolar electrodialysis & $\mathrm{kWh} / \mathrm{t}$ & 33 \\
Reverse osmosis & $\mathrm{kWh} / \mathrm{t}$ & 4.28 \\
Distillation & $\mathrm{kWh} / \mathrm{t}$ & 1.32 \\
\hline
\end{tabular}

4

5 
1 SI-4. Process flow diagram of the standalone systems and the integrated system

2 The details on the energy flows within the biorefinery systems and the energy exchanges

3 between the two standalone systems for System C are shown in Fig. S-4.1. The notations as

4 mentioned in the Fig. S-4.1 are: Gross $E_{\text {in-Total }}=$ total energy required in the biorefinery

5 systems; $\mathrm{E}_{\text {out }}=$ Energy produced from the CHP plants (after deducting the self-demand, e.g.

6 to burn the fuel); $E_{\text {in-GBR }}=$ Energy input to System B; $E_{\text {in-EtOH }}=$ Energy input to System A;

$7 \quad \mathrm{E}^{*}{ }_{\text {out }}=$ co-produced energy from the CHP plants; Net $\mathrm{E}_{\text {in-Total }}=$ Energy required in the

8 biorefinery after accounting all internal consumptions and Net $E_{\text {out-surplus }}=$ surplus electricity

9 production from the system

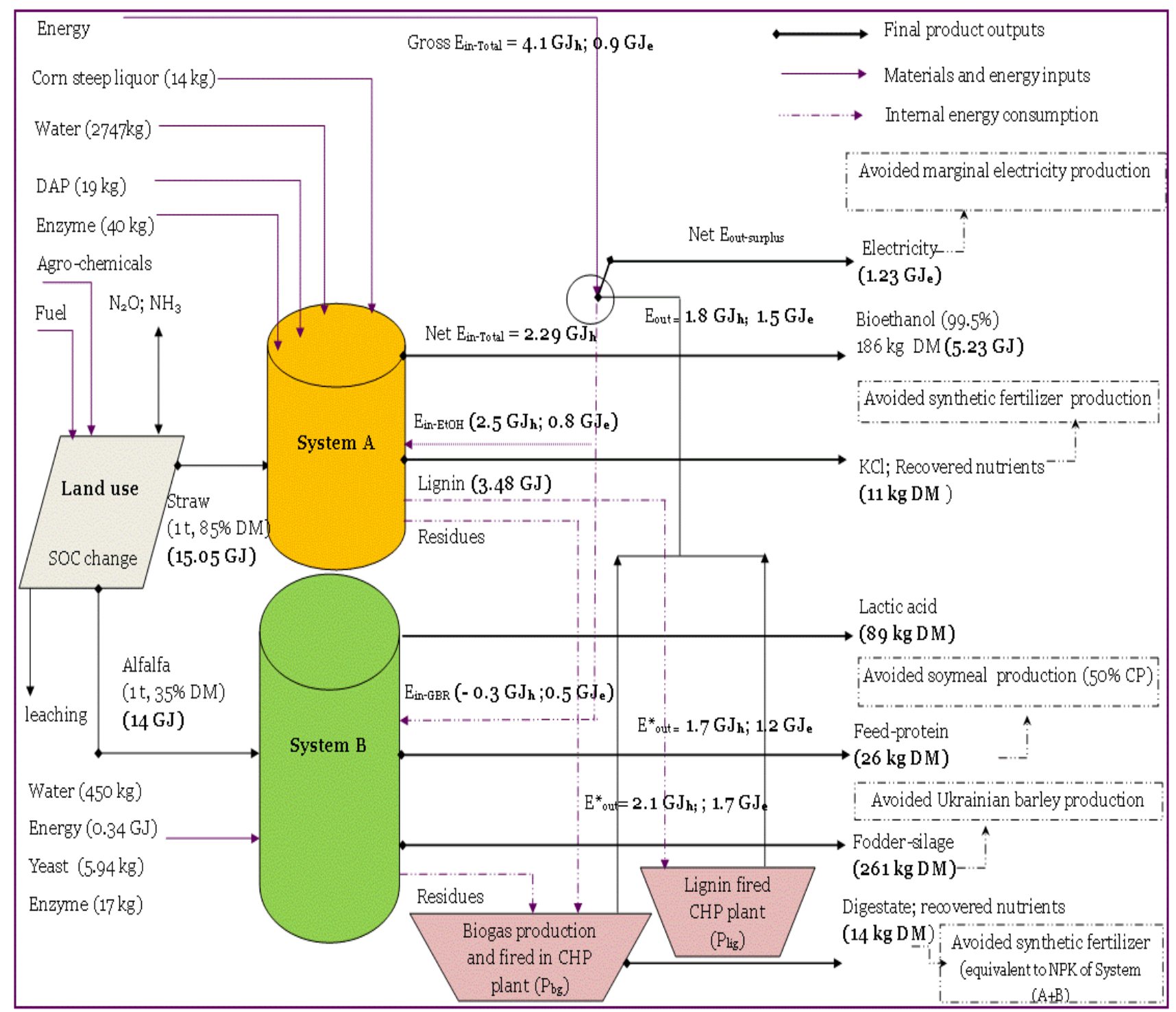

11 Fig. S-4.1. Materials and energy flows in the integrated system (System C).Electricity 12 produced is the net values after utilizing the internal consumptions in each standalone 13 systems. 
1 SI-5. Transformation of biomass in System A

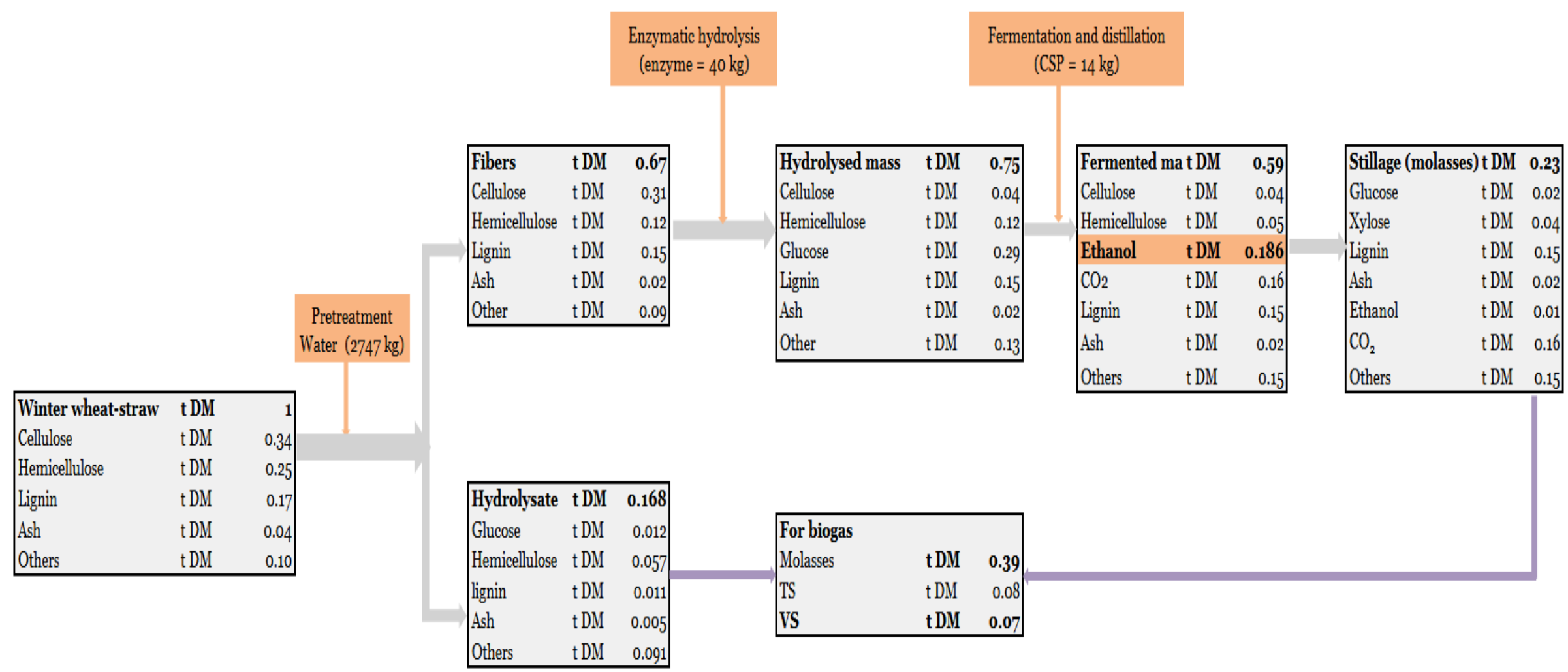

3 Fig. S-5.1. Mass flow for the conversion of straw to bioethanol, mass balance averaged from studies Bentsen et al. (2006), Kaparaju et al. 4 (2009) and Wang et al. (2013). 
SI-6. Transformation of biomass in System B

2 Regarding the processes involved for the production of lactic acid, it was assumed that it 3 initiates with handling of alfalfa with mechanical processing, including the chopping of the biomass. The process was assumed to be followed by the extraction of press-juice (DM 5 \%) and press-cake from a mechanical screw-press (O’Keeffe et al., 2011). The fractions of press juice and the press cake were assumed to be $70 \%$ and $30 \%$ of the fresh matter respectively (O’Keeffe et al., 2011). Fiber losses (5\% of the total fibers in biomass) during the washing steps were assumed to be recovered and utilized as residues for biogas production (see Fig. S6.1). Press juice-stream was divided into two sub-streams, one for the protein extraction and another for the lactic acid production (Kamm et al., 2009; O'Keeffe et al., 2011). After the separation of press-juice and press cake, the DM content in the press cake (i.e. after the $2^{\text {nd }}$ pressing) was assumed for hydrothermal pre-treatment process, followed by enzymatic hydrolysis. The amount of enzyme used during the hydrolysis process was calculated based on the cellulose content of the press cake. Enzyme loading per cellulose content of the pretreated biomass (Bentsen et al., 2006; Kaparaju et al., 2009) was considered to calculate the amount of enzyme. The calculated mass of enzyme was $17 \mathrm{~kg}$ per ton dry biomass, and was comparable to the loading rate of $20 \mathrm{~kg}$ per ton biomass, as reported in Wolfrum et al. (2013). It was also close to the value reported (51 kg per kg press cake), reported in Duque (2016). Cellulose content in the press cake was assumed 33\% of the total fibers (DM) of the press cake (PC) (see Fig S-6.1). The assumption was within the range (20-36\%), as reported in Xiu et al. (2014). It was reported to be around $44 \%$ in clover grass cake (reported for the initial hour of pretreatment) (Duque, 2016). The sugar content in the fibers (input and output streams) (Table S-6.1) was assumed after Cybulska et al. (2010). Considering these, glucose in the liquid and solid fractions (i.e. of the hydrolysed materials) were assumed $1.3 \%$ and $32 \%$ respectively of the sugar content in the press cake (Table S-6.1). Considering the uncertainty to harness glucose in both fractions, in the current study only the glucose contained in the solid fractions was considered for the fermentation process. Yield of glucose after the hydrolysis process was estimated to be $125 \mathrm{~kg}$ per t DM of the solid fraction (see Fig. S-6.1 and Table S-6.1). Regarding the fermentation of the substrate, a lactic acid producing 
1 bacteria can be considered (Pahlow et al., 2003). In order to overcome the inhibitory effect 2 during the fermentation process, fermentation takes can be carried out in a continuous 3 dialysis process or in an electro-dialysis system (Kim and Moon, 2001). In the current study, 4 for the recovery of lactic acid and protein following processes were considered: ultrafiltration, 5 reverse osmosis (Patel et al., 2006), bipolar electro-dialysis and distillation (Kim and Moon, 6 2001). Energy consumption for these processes is summarized in Table S-3.1. Feed protein 7 contained in the fermentation broth was assumed to be separated using an ultrafiltration membrane technology ( $\mathrm{Li}$ et al., 2006). Sodium hydroxide was used as a base material, which results into sodium lactate. The total yield of lactic acid was calculated from the press-juice fraction and the fraction obtained after the fermentation of glucose, as stated above. Crude lactic acid (26 kg lactic acid per t DM) contained in the press juice with an extraction efficiency of 70\% resulted to produce $18 \mathrm{~kg}$ LA (DM) (O'Keeffe et al., 2011). Likewise, considering the glucose to lactic acid conversion factor to be $79 \%$ (Doran-Peterson et al., 2008), the total production of biobased lactic acid was estimated to be $89 \mathrm{~kg}$ (SI-6). Liquid residue produced from the processing of biomass was considered as substrate for biogas production.

Table S-6.1: Material balance after the conversion of dry matter of the press cake undergoing enzymatic hydrolysis process, calculation based on Cybulska et al. (2010).

\begin{tabular}{lcccccc}
\hline \multirow{2}{*}{ Components } & \multicolumn{2}{c}{ Input $^{*}$} & \multicolumn{3}{c}{ Output } \\
\cline { 2 - 7 } & & & \multicolumn{2}{c}{ Liquid } & \multicolumn{2}{c}{ Solid } \\
\cline { 2 - 7 } & $33 \%$ & $\mathrm{~kg}$ & $\%$ & $\mathrm{~kg}$ & $\%$ & $\mathrm{~kg}$ \\
\hline Glucose & 133 & $1.3 \%$ & 5 & $31 \%$ & 125 \\
Hemicellulose & $15.60 \%$ & 63 & $5.90 \%$ & 24 & $9.70 \%$ & 39 \\
Lignin & $21 \%$ & 85 & $18.50 \%$ & 75 & $2.50 \%$ & 10 \\
Ash & $5.65 \%$ & 23 & $0.00 \%$ & 0.000 & $5.65 \%$ & 23 \\
\hline
\end{tabular}




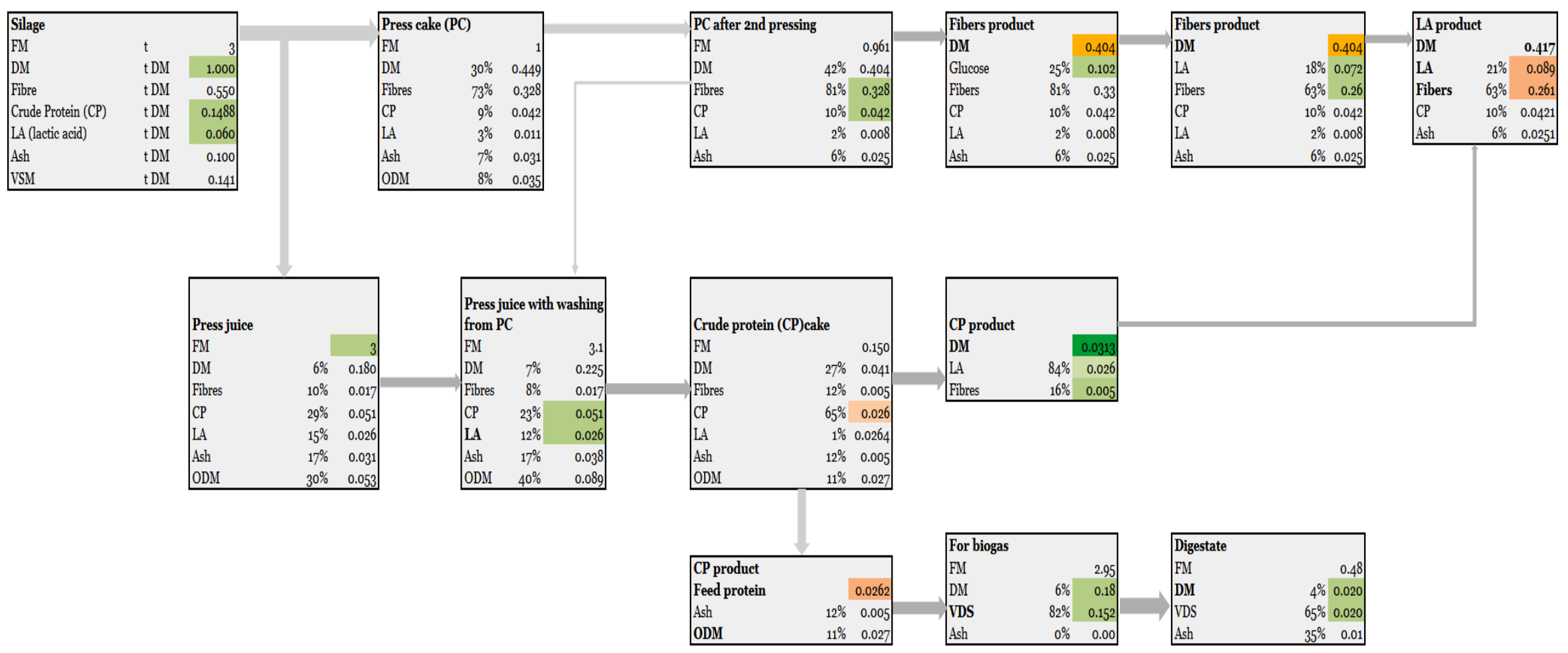

2 Fig.S-6. 1: Mass flow for the conversion of alfalfa to lactic acid and other biobased products, data partly adapted from (O’Keeffe et al., 2011) and 3 adjusted for DM content of fresh alfalfa to 35\%. Glucose content were based on Cybulska et al. (2010) (see text and Table S-6.1), and the 4 conversion factor of the glucose in the associated fraction was based on Doran-Peterson et al. (2008). The production of LA as presented in the 5 fraction "press juice with washing from press cake (PC)" indicates the yield assumed after enzymatic hydrolysis plus the conversion of crude LA 6 contained in the press juice. 'Green' shaded parts represent the depending intermediate particles and 'orange' shaded parts indicate the final 7 product. All data presented are in t DM, calculated from the fresh matter (FM), composition of each chemicals are with respect to the DM 8 mentioned. 
Reference List

Bentsen, N. S., Felby, C., Ipsen, K. H., 2006. Energy balance of 2 nd generation bioethanol production in Denmark. 1-

45.http:// www.tekno.dk/ pdf/ projekter/ p09 2gbio/ClausFelby/ p09 2gbio\%20Bents en\%20et\%20al\%20(2006).pdf (accessed May 05, 2014).

Berglund, M., Börjesson, P., 2006. Assessment of energy performance in the life-cycle of biogas production Biomass and Bioenergy 2006; 30: 254-266.

Cybulska, I., Lei, H., J ulson, J ., 2010. Hydrothermal Pretreatment and Enzymatic Hydrolysis of Prairie Cord Grass Energy \& Fuels 2010; 24: 718-727.

Doran-Peterson, J ., Cook, D. M., Brandon, S. K., 2008. Microbial conversion of sugars from plant biomass to lactic acid or ethanol The Plant J ournal 2008; 54: 582-592.

Drosg, B., Fuchs, W., Meixner, K., Waltenberger, R., Kirchmayr, R., Braun, R., Bochmann, G., 2012. Anaerobic digestion of stillage fractions - estimation of the potential for energy recovery in bioethanol plants Water Science and Technology 2012; 67: 494-505.

Duque, A. d. B., 2016. Enhancing protein and sugar extraction from grasses in a biorefinery concept by enzymatic hydrolysis and ensiling of the press cake. M.Sc. thesis. Department of Biotechnology, Chemistry and Environmental Engineering, Aalborg University, Denmark. 1-

70.http://projekter.aau.dk/projekter/files/239506841/Master Thesis Alejandro de 1 Barrio.pdf (accessed Feb 22, 2017).

Hamelin, L., J ørgensen, U., Petersen, B. M., Olesen, J . E., Wenzel, H., 2012. Modelling the carbon and nitrogen balances of direct land use changes from energy crops in Denmark: a consequential life cycle inventory Global Change Biology Bioenergy 2012; 4: 889-907.

J ørgensen, P. J ., 2009. Biogas-green energy. Faculty of Agricultural Sciences, Aarhus University, Tjele, Denmark. 1-34.http:// www.lemvigbiogas.com/BiogasPJ J uk.pdf (accesed April 14, 2016).

Kamm, B., Hille, C., Schönicke, P., Dautzenberg, G., 2010. Green biorefinery demonstration plant in Havelland (Germany) Biofuels, Bioproducts and Biorefining 2010; 4: 253262.

Kamm, B., Schönicke, P., Kamm, M., 2009. Biorefining of Green Biomass - Technical and Energetic Considerations CLEAN - Soil, Air, Water 2009; 37: 27-30.

Kaparaju, P., Serrano, M., Thomsen, A. B., Kongjan, P., Angelidaki, I., 2009. Bioethanol, biohydrogen and biogas production from wheat straw in a biorefinery concept Bioresource Technology 2009; 100: 2562-2568.

Kim, Y. H., Moon, S.-H., 2001. Lactic acid recovery from fermentation broth using one-stage electrodialysis J ournal of Chemical Technology \& Biotechnology 2001; 76: 169-178.

Li, Y., Shahbazi, A., Kadzere, C. T., 2006. Separation of cells and proteins from fermentation broth using ultrafiltration J ournal of Food Engineering 2006; 75: 574-580.

Møller, J., Thøgersen, R., Helleshøj, M. E., Weisbjer, M., Søegaard, K., Hvelplund, T., 2005. Fodermiddltabel 2005. Sammensætning og foderværdi af fodermidler til kvæg. Rapport nr. 112. SEGES, Aarhus, Denmark. . 165.https:// www.landbrugsinfo.dk/ kvaeg/foder/sider/fodermiddeltabel_2005.aspx (accessed J uly 22, 2015). 
NaturErhvervstyrelsen, 2015. Vejledning om gødsknings-og harmoniregler: Planperioden 1. august 2014 til 31. juli 2015. Document number 6. Agriculture and Fisheries (in Danish). Ministeriet for Fødevarer, Landbrug og Fiskeri,Copenhagen, Denmark. . 1173.http:// www.nordfynskommune.dk/ / media/Files/Dokumenter/ Teknik\%20og\% 20Miljoe/ Natur\%20og\%20Miljoe/ Landbrug/Vejledning\%20om\%20g\%C3\%B8dnings -\%20og\%20harmoniregler.pdf (accessed May 15, 2015).

O’Keeffe, S., Schulte, R. P. O., Sanders, J . P. M., Struik, P. C., 2011. I. Technical assessment for first generation green biorefinery (GBR) using mass and energy balances: Scenarios for an Irish GBR blueprint Biomass and Bioenergy 2011; 35: 4712-4723.

Olesen, J . E., Weiske, A., Asman, W. A., Weisbjerg, M. R., Djurhuus, J ., Schelde, K., 2004. FarmGHG. A model for estimating greenhouse gas emissions from livestock farms. Internal Report No. 202. Danish Institute of Agricultural Sciences.http:/ / agrsci.au.dk/ fileadmin/DJ F/JPM/ Klima/J EO/ FarmGHG.zip (accessed Jan 04, 2013).

Pahlow, G., Muck, R. E., Driehuis, F., Elferink, S. J . W. H. O., Spoelstra, S. F., 2003. Microbiology of Ensiling. In: Buxton DR, Muck RE, Harrison J H, editors. Silage Science and Technology. American Society of Agronomy, Crop Science Society of America, Soil Science Society of America, Madison, WI, 2003, pp. 31-93.

Parajuli, R., Knudsen, M. T., Djomo, S. N., Corona, A., Birkved, M., Dalgaard, T., 2017. Environmental Life Cycle Assessment of producing willow, alfalfa and straw from spring barley as feedstocks for bioenergy or biorefinery systems. Accepted in Science of the Total Environment. DOI: 10.1016/j.scitotenv.2017.01.207 2017.

Patel, M., Crank, M., Dornburg, V., Hermann, B., Roes, L., Hüsing, B., . . Recchia, E., 2006. Medium and Long-term Opportunities and Risks of the Biotechnological Production of Bulk Chemicals from Renewable Resources-The Potential of White Biotechnology. Final report. Prepared under the European Commission's GROWTH Programme (DG Research). Utrecht University, Department of Science, Technology and Society (STS) / Copernicus Institute, Heidelberglaan 2, NL-3584 CS Utrecht, Netherlands. 1444.http:// www.bio-economy.net/applications/files/Brew project report.pdf / accessed April 23, 2016).

Pugesgaard, S., Olesen, J. E., J ørgensen, U., Dalgaard, T., 2013. Biogas in organic agriculture - effects on productivity, energy self-sufficiency and greenhouse gas emissions Renewable Agriculture and Food Systems 2013; 29: 28-41.

SEGES, 2010. Growing instructions-Crops. SEGES, Agro Food Park, Aarhus, Denmark. https://dyrkplant.dlbr.dk/ Web/ (S(pgsviibw4c1053wjgai5ni1p))/ forms/Afgroeder.aspx?kategori=1 (accessed Sep 12, 2015).

Wang, L., Littlewood, J., Murphy, R. J ., 2013. Environmental sustainability of bioethanol production from wheat straw in the UK Renewable \& Sustainable Energy Reviews 2013; 28: 715-725.

Wolfrum, E. J ., Ness, R. M., Nagle, N. J ., Peterson, D. J., Scarlata, C. J ., 2013. A laboratoryscale pretreatment and hydrolysis assay for determination of reactivity in cellulosic biomass feedstocks Biotechnol Biofuels 2013; 6: 162. 
1 Xiu, S., Shahbazi, A., Boakye-Boaten, N. A., 2014. Effects of Fractionation Methods on the 2 Isolation of Fiber-rich Cake from Alfalfa and Ethanol Production from the Cake. Vol 39 9, 2014.

4 